\title{
Paleoceanography
}

\section{RESEARCH ARTICLE \\ 10.1002/2014PA002741 \\ Upper ocean oxygenation dynamics from I/Ca ratios during the Cenomanian-Turonian OAE 2}

Key Points:

- Upper ocean oxygenation levels are highly dynamic across OAE 2

- A shallow $\mathrm{O}_{2}$ oasis in proto-Atlantic is supported by proxy and model

- I/Ca is a proxy for local redox, not for weathering and carbon burial

Supporting Information:

- Table S1 and Text S1

Correspondence to:

Z. Lu,

zunlilu@syr.edu

\section{Citation:}

Zhou, X., H. C. Jenkyns, J. D. Owens, C. K. Junium, X.-Y. Zheng, B. B. Sageman, D. S. Hardisty, T. W. Lyons, A. Ridgwell, and Z. Lu (2015), Upper ocean oxygenation dynamics from $\mathrm{I} / \mathrm{Ca}$ ratios during the Cenomanian-Turonian OAE 2, Paleoceanography, 30, 510-526, doi:10.1002/2014PA002741

Received 16 OCT 2014 Accepted 8 APR 2015 Accepted article online 14 APR 2015 Published online 13 MAY 2015
(C2015. American Geophysical Union. All Rights Reserved.

\author{
Xiaoli Zhou ${ }^{1}$, Hugh C. Jenkyns ${ }^{2}$, Jeremy D. Owens ${ }^{3}$, Christopher K. Junium ${ }^{1}$, Xin-Yuan Zheng ${ }^{4}$, \\ Bradley B. Sageman ${ }^{5}$, Dalton S. Hardisty ${ }^{6}$, Timothy W. Lyons ${ }^{6}$, Andy Ridgwell, and Zunli Lu ${ }^{1}$ \\ ${ }^{1}$ Department of Earth Sciences, Syracuse University, Syracuse, New York, USA, ${ }^{2}$ Department of Earth Sciences, University of \\ Oxford, Oxford, UK, ${ }^{3}$ Woods Hole Oceanographic Institution, Woods Hole, Massachusetts, USA, ${ }^{4}$ Department of Geoscience, \\ University of Wisconsin-Madison, Madison, Wisconsin, USA, Department of Earth and Planetary Sciences, Northwestern \\ University, Evanston, Illinois, USA, ${ }^{6}$ Department of Earth Sciences, University of California, Riverside, California, USA, ${ }^{7}$ School \\ of Geographical Sciences, University of Bristol, Bristol, UK
}

Abstract Global warming lowers the solubility of gases in the ocean and drives an enhanced hydrological cycle with increased nutrient loads delivered to the oceans, leading to increases in organic production, the degradation of which causes a further decrease in dissolved oxygen. In extreme cases in the geological past, this trajectory has led to catastrophic marine oxygen depletion during the so-called oceanic anoxic events (OAEs). How the water column oscillated between generally oxic conditions and local/global anoxia remains a challenging question, exacerbated by a lack of sensitive redox proxies, especially for the suboxic window. To address this problem, we use bulk carbonate I/Ca to reconstruct subtle redox changes in the upper ocean water column at seven sites recording the Cretaceous OAE 2. In general, I/Ca ratios were relatively low preceding and during the OAE interval, indicating deep suboxic or anoxic waters exchanging directly with near-surface waters. However, individual sites display a wide range of initial values and excursions in I/Ca through the OAE interval, reflecting the importance of local controls and suggesting a high spatial variability in redox state. Both I/Ca and an Earth System Model suggest that the northeast proto-Atlantic had notably higher oxygen levels in the upper water column than the rest of the North Atlantic, indicating that anoxia was not global during OAE 2 and that important regional differences in redox conditions existed. A lack of correlation with calcium, lithium, and carbon isotope records suggests that neither enhanced global weathering nor carbon burial was a dominant control on the I/Ca proxy during OAE 2.

\section{Introduction}

\subsection{Marine Environmental Changes During Oceanic Anoxic Events}

The concept of oceanic anoxic events (OAEs) was introduced upon the discovery of globally deposited coeval marine organic-rich sediments (black shales) of Cretaceous age, a phenomenon associated directly and indirectly with profound environmental and chemical changes [Schlanger and Jenkyns, 1976; Schlanger et al., 1987; Arthur et al., 1990; Jenkyns, 2003, 2010]. Globally recorded OAEs are recognized as the early Toarcian or T-OAE ( 182 Ma) from the Jurassic Period and OAE 1a in the early Aptian ( 125 Ma) and OAE 2 ( 94 Ma) at the Cenomanian-Turonian boundary from the Cretaceous Period [Ogg and Hinnov, 2012a, 2012b].

During OAE 2, positive carbon isotope excursions ( $\mathrm{CIES}$ ) in both inorganic and organic carbons are found in different environmental settings [Jarvis et al., 2011]. Because organic carbon has strongly negative $\delta^{13} \mathrm{C}$ values, ranging from -25 to $-60 \%$, enhanced rates of organic carbon burial left residual seawater with relatively high carbon isotope values in dissolved inorganic carbon, producing carbonates and organic matter with elevated $\delta^{13} \mathrm{C}$. These positive CIEs, together with macrofossil, microfossil, and nannofossil biostratigraphy, allow correlation of stratigraphic columns from different OAE 2 sections [Tsikos et al., 2004].

Before the CIE started, different proxies suggest that $\mathrm{CCO}_{2}$ was unusually high [Jarvis et al., 2011], likely introduced by volcanic and hydrothermal activities [Jones and Jenkyns, 2001; Kuroda et al., 2007] related to the formation of the Caribbean and other Large Igneous Provinces [Wignall, 2001; Erba, 2004; Turgeon and Creaser, 2008; Zheng et al., 2013; Du Vivier et al., 2014]. Addition of $\mathrm{CO}_{2}$ to the atmosphere would have increased global temperature, which enhanced the hydrological cycle and delivered more nutrients to the ocean. In turn, enhanced nutrient availability would have stimulated planktonic productivity, increasing 
the oxygen demand in the water column as well as fostering burial of more organic carbon in marine sediments [Weissert, 1989; Jenkyns, 2003; Adams et al., 2010]. A positive excursion of sulfur isotopes in bulk carbonates of Cenomanian-Turonian age indicates that sulfate reduction and enhanced rates of pyrite burial became more significant globally as bottom water euxinia expanded during OAE 2 [Ohkouchi et al., 1999; Owens et al., 2013]. Consistent with this observation, there is considerable biomarker evidence indicating episodic but widespread photic zone sulfide accumulation (euxinia) in the North and South Atlantic regions, the proto-Indian Ocean, and in the Tethys [Sinninghe Damsté and Koster, 1998; Kuypers et al., 2002; Pancost et al., 2004; Forster et al., 2008; van Bentum et al., 2009].

Beyond the sulfur, carbonate, and organic matter isotope records, the inorganic elemental proxies applied to OAE 2 are mostly restricted to concentrations and elemental ratios of redox-sensitive metals in shales (e.g., $\mathrm{Mn}, \mathrm{Mo}, \mathrm{V}, \mathrm{Fe}, \mathrm{U}, \mathrm{Co}, \mathrm{Ce}$, and $\mathrm{Cd}$ ), although metal isotopes are being increasingly used. Trace metals precipitate as sulfides under anoxic and euxinic conditions, some with valence changes (e.g., Mo and V) and some without, such as $\mathrm{Zn}$ [Hetzel et al., 2009]. During OAE 2, some trace metals, such as As, Bi, Cd, Co, $\mathrm{Cr}, \mathrm{Cu}, \mathrm{Mo}, \mathrm{Ni}, \mathrm{Sb}, \mathrm{Tl}, \mathrm{V}$, and $\mathrm{U}$, were concentrated in organic matter or precipitated with sulfide, suggesting euxinia in the sediments and/or in the water column [Arthur et al., 1990; Kuypers et al., 2002; Jenkyns, 2010], as documented for the proto-Atlantic [Kuypers et al., 2002; Kolonic et al., 2005; Brumsack, 2006; Forster et al., 2008; Hetzel et al., 2009; Tribovillard et al., 2012; van Helmond et al., 2014; Little et al., 2015] and for southern Europe [Scopelliti et al., 2006, 2008; Turgeon and Brumsack, 2006]. Molybdenum isotope data [Westermann et al., 2014] and uranium isotope data [Montoya-Pino et al., 2010] also indicate expanded bottom water euxinia during the OAE 2. Although these geochemical species are interpreted as paleoredox tracers, they may also have responded to changes in hydrothermal flux that may have further contributed to metal enrichments during OAE 2 [Orth et al., 1993; Snow et al., 2005; Elrick et al., 2009; Jenkyns, 2010; Eldrett et al., 2014].

The details of how the global ocean evolved from relatively widespread oxidizing conditions, with only localized anoxia in restricted marine settings and areas of particularly high primary production, to globally extensive anoxia [Pancost et al., 2004; Hetzel et al., 2009; Montoya-Pino et al., 2010; Owens et al., 2013] remain unclear for OAE 2 and OAEs more generally. Newly developed geochemical techniques utilizing the biophilic element iodine in carbonates help to bridge this gap and shed novel light on the geographic patterns and controls on the development of anoxia.

\section{2. $\mathrm{I} / \mathrm{Ca}$ as a Paleoredox Proxy}

Although iodine can exist in several oxidation states, iodide $\left(\mathrm{I}^{-}\right)$and iodate $\left(\mathrm{IO}_{3}{ }^{-}\right)$are the thermodynamically stable inorganic forms in seawater. The standard reduction potential of $\mathrm{IO}_{3}{ }^{-} / \mathrm{I}^{-}$is very close to that of $\mathrm{O}_{2} / \mathrm{H}_{2} \mathrm{O}$ [Rue et al., 1997; Harris, 2006], making iodine one of the first elements to respond to oceanic deoxygenation. Most of the iodine in the modern well-oxygenated ocean occurs as iodate [Wong, 1995; Farrenkopf et al., 1997; Campos et al., 1999; Waite et al., 2006]. Because only iodate precipitates with carbonate, the simple presence of carbonate-associated iodine requires locally oxic conditions in the water column. lodate is, however, almost completely reduced to iodide in all investigated modern anoxic basins and oxygen minimum zones where dissolved $\mathrm{O}_{2}$ is less than $3 \mu \mathrm{M}$ [Wong and Brewer, 1977; Wong et al., 1985; Luther and Campbell, 1991; Farrenkopf et al., 1997; Rue et al., 1997; Farrenkopf and Luther, 2002]. Consequently, a drop in iodate concentration to $\sim 0$ indicates strong deoxygenation within the local water column.

I/Ca ratios in calcite increase linearly with iodate concentrations in the precipitating medium, but iodide does not incorporate into carbonate [Lu et al., 2010]. The mechanism of iodate incorporation is unclear but may involve substitution for the carbonate ion and/or the presence of lattice defects, perhaps analogous to the mechanism proposed for sulfate incorporation into carbonate [Staudt and Schoonen, 1995]. The lack of iodide incorporation is likely due to the large ionic radius of iodide relative to iodate.

Most pelagic carbonate is produced within the upper levels of the water column as coccolith and planktonic foraminiferal calcite, which in recent environments falls to the seafloor roughly in the proportion of 1:1 [Broecker and Clark, 2009]. Hence, a bulk carbonate chemical signal should reflect conditions in near-surface waters. Although the percentage of biogenic carbonate produced at the seafloor is generally very small, the influence of benthic calcifiers cannot be ruled out. For these reasons, the bulk carbonate I/Ca ratio in this work is taken as an indicator for the integrated conditions in the upper ocean water column. 
Once oxic conditions are established, iodine speciation at a given location is secondarily influenced by regional mixing. The kinetics of iodide oxidation are not well constrained [Luther et al., 1995] but are currently estimated to be slow, with the lifetime of iodide in oxygenated waters ranging from months to several decades [Chance et al., 2014]. Since iodide is not oxidized instantaneously, upwelling of anoxic (iodide-rich) waters from anoxic basins or oxygen minimum zones (OMZs) to well-oxygenated surface waters results in lower iodate concentrations compared to those in the open ocean, promoting accumulation of bulk carbonate with relatively low I/Ca ratios. Such a decrease in bulk I/Ca does not necessarily represent lower dissolved oxygen levels in the mixed layer but instead reflects redox conditions in the underlying water masses that are in direct exchange with near-surface waters.

From a global perspective, local I/Ca ratios are also expected to reflect potential significant shifts in the size of the marine iodine reservoir. The contemporary marine iodine budget is not accurately constrained. However, the iodine fluxes (e.g., river and mantle inputs, output of organic matter burial) in and out of seawater are estimated to be 1 to 2 orders of magnitude lower than the amount of iodine associated with biological production [Lu et al., 2010, and references therein]. The biological pump results in some iodate loss from mixed-layer waters in high-productivity regions. Such surface depletions have been observed at stations off Hawaii, Bermuda [Campos et al., 1996], the Weddell Sea [Bluhm et al., 2011; Campos et al., 1999], Mediterranean Sea [Tian et al., 1996], Arabian Sea [Farrenkopf and Luther, 2002], and an Antarctic coastal site [Chance et al., 2010]. Most of this iodine is released back into the seawater during the decomposition of organic matter in an oxic water column [Lu et al., 2010, and references therein], but organic carbon burial results in a large flux of iodine to the sediments. Consequently, enhanced primary production should export more organic iodine out of the mixed layer, lowering total iodine concentration and hence lowering I/Ca in bulk carbonate. If the burial of organic carbon can lead to global iodine drawdown, it is anticipated that $\mathrm{I} / \mathrm{Ca}$ decreases will generally correlate with increases in $\delta^{13} \mathrm{C}$.

Bulk carbonate I/Ca signals may be affected by other factors in addition to the local upper ocean redox conditions. Mixing with diagenetic carbonate or recrystallization of primary carbonate in anoxic pore waters should lower the I/Ca values, since iodide, the only inorganic iodine species in anoxic marine or pore waters [Wong and Brewer, 1977; Wong et al., 1985; Kennedy and Elderfield, 1987a, 1987b; Luther and Campbell, 1991; Farrenkopf et al., 1997; Rue et al., 1997; Farrenkopf and Luther, 2002], cannot be incorporated into carbonate [Lu et al., 2010]. Therefore, carbonates with obvious diagenetic features should be avoided for measurements of I/Ca.

\subsection{Multiproxy Comparisons}

New I/Ca data presented and discussed in this study represent several end-member locations recording OAE 2, covering different paleowater depths, paleolatitudes, organic carbon contents, and accumulation rates (Figure 1 and Table 1). Sulfur isotope data [Adams et al., 2010; Owens et al., 2013] are compared with our I/Ca records to further constrain the global redox conditions. Relatively low $\mathrm{l} / \mathrm{Ca}$ values found at multiple sections recording the OAE may indicate widespread oxygen-depleted conditions. For example, during the early Toarcian OAE, a section of shallow-water carbonates recorded an I/Ca decrease of $\sim 4 \mu \mathrm{mol} / \mathrm{mol}$ in phase with the onset of positive carbon isotope excursion (CIE) and coincided tightly with the beginning of a large shift in the sulfur isotope composition of carbonate-associated sulfate [Lu et al., 2010; Gill et al., 2011].

The $\delta^{34} S_{\text {CAS }}$ can provide useful information about changes in paleoredox, but it could be affected by multiple environmental changes, such as changes in the input from continental weathering, volcanism, and hydrothermal activity; pyrite and evaporite deposition; and the availability of sulfate, iron, and organic matter [e.g., Paytan et al., 2004]. However, recording a positive $\delta^{34} S_{\text {CAS }}$ excursion in multiple ocean basins over a short event is nearly impossible without the burial of isotopically light sulfur, most plausibly from a global increase in pyrite burial. Importantly, although $\mathrm{I} / \mathrm{Ca}$ and $\delta^{34} \mathrm{~S}$ are expected to show general similarities in their behavior during major oxygenation changes, they will not necessarily covary precisely, due to their distinct biogeochemical behaviors [Hardisty et al., 2014]. In the modern ocean, the residence time for sulfate is 10-15 Myr [Walker, 1986], which is much longer than the $300 \mathrm{kyr}$ estimated for iodine [Broecker and Peng, 1982], although this residence time is likely to have been different during the OAE 2 since oceanic sulfate concentrations perhaps were $\sim 1 / 4$ of the modern value ( $7 \mathrm{mM}$ versus $28 \mathrm{mM}$ ) [Paytan et al., 2004; Owens et al., 2013]. Generally, however, $\delta^{34} S_{\text {CAS }}$ should illustrate dominantly a global signal and I/Ca a local one. 


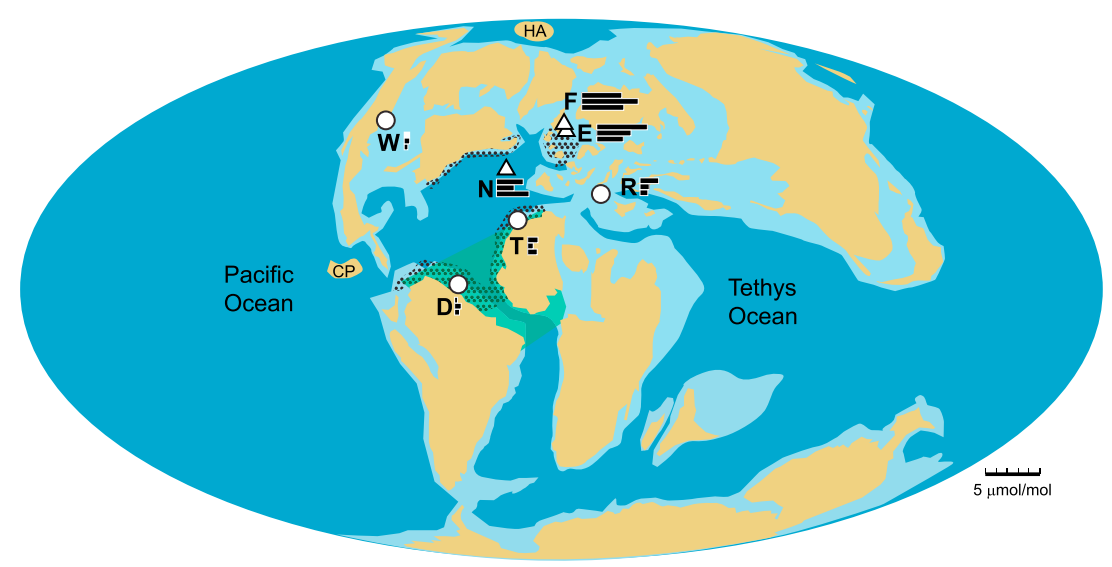

Figure 1. Global paleogeographic map of OAE 2 sections. The yellow represents the continents, the light blue stands for shallow oceans, and the dark blue for deep oceans. The black dots mark the modeled upwelling regions from Topper et al. [2011], and the green shading shows areas of euxinic conditions in the water column given in Jenkyns [2010]. The studied sites are grouped into oxic (white triangles) and hypoxic (white circles) sites, and the site names are abbreviated. See Table 1 for abbreviations for site names. Average $\mathrm{I} / \mathrm{C}$ a values during pre-CIE, CIE, and post-CIE intervals are shown as uniformly scaled bars from bottom to top for individual sites. CP is Caribbean Plateau, and HA is High Arctic Large Igneous Province.

Calcium and lithium isotopes are important markers for crustal weathering rates during OAE 2 [Blättler et al., 2011; Pogge von Strandmann et al., 2013]. These isotopic records are also examined to illuminate any potential influence of weathering on the marine iodine budget and I/Ca signals. Finally, the oceanographic I/Ca pattern is linked to the oxygenation conditions modeled in the Grid Enabled Integrated Earth System Model (GENIE) [Monteiro et al., 2012].

\section{Study Sites}

New I/Ca data are reported from seven sections and compared with the previously published data from Eastbourne, UK (Table 1) [Lu et al., 2010; Tsikos et al., 2004]. The sections are mostly located either within or peripheral to the proto-Atlantic Ocean (Figure 1). This sample set covers a variety of paleowater depths and lithologies from shallow-water platform carbonates to pelagic chalks and shales. Material from Raia del Pedale, Italy; Eastbourne, UK; South Ferriby, UK; and Newfoundland Drifts, northwestern Atlantic are mostly organic-lean carbonates, although the latter two sites contain thin (centimeter-scale) black organic-rich shales. The Aristocrat Angus core in the U.S. Western Interior Seaway (WIS) and at Demerara Rise, offshore Suriname and the Tarfaya (Morocco) site, have relatively elevated total organic carbon (TOC) in marls and shales (commonly $>5 \%$ ) throughout the studied interval.

\begin{tabular}{|c|c|c|c|c|}
\hline Label & Location & $\begin{array}{l}\text { Deposition } \\
\text { Environment }\end{array}$ & Lithology & Reference \\
\hline $\mathrm{R}$ & Raia del Pedale, Italy & Shallow water & Limestone & Parente et al. [2008] \\
\hline W & $\begin{array}{l}\text { Aristocrat Angus core, } \\
\text { Western Interior Seaway }\end{array}$ & Shallow water & Limestone/shale & Joo and Sageman [2014] \\
\hline D & Demerara Rise, ODP 1258 & Low-latitude, Pelagic & $\begin{array}{c}\text { Organic-rich } \\
\text { limestone/Black shale }\end{array}$ & $\begin{array}{l}\text { Hetzel et al. [2009]; } \\
\text { Erbacher et al. [2005] }\end{array}$ \\
\hline $\mathrm{T}$ & Tarfaya, Morocco & Low-latitude, Pelagic & $\begin{array}{c}\text { Organic-rich } \\
\text { Chalk/Black shale }\end{array}$ & Jenkyns et al. [2007] \\
\hline $\mathrm{E}$ & Eastbourne, UK & Midlatitude, Pelagic & Chalk & Pearce et al. [2009] \\
\hline $\mathrm{F}$ & South Ferriby, UK & Midlatitude, Pelagic & Chalk/Black shale & Jenkyns et al. [2007] \\
\hline N & $\begin{array}{l}\text { Newfoundland Drifts, } \\
\text { IODP U1407 }\end{array}$ & Midlatitude, Pelagic & Chalk/Black shale & Expedition 342 Scientists [2012] \\
\hline
\end{tabular}

${ }^{\mathrm{a}}$ Abbreviations are used in the site map. 


\section{Analytical Methods}

\subsection{Sample Preparation and Measurements}

Powdered samples (3-5 mg) from different lithological settings were weighed out on a microgram balance and then rinsed with deionized water to remove dissolvable iodine salt potentially attached to the surface of the samples. Next, a volume of nitric acid (3\%) was calculated according to sample weight, and the acid was added to each sample in a sonicating bath to allow complete dissolution of the carbonate. Residual noncarbonate impurities were removed by centrifuging. The final solutions for the inductively coupled plasma-mass spectrometry (ICP-MS) measurements contain approximately $50 \mathrm{ppm} \mathrm{Ca}$ and $0.5 \%$ tertiary amine to help stabilize iodate [Schnetger and Muramatsu, 1996] and internal standards. For each batch of measurements, pure potassium iodate was dissolved and diluted as a calibration standard. I/Ca was measured on a quadrupole ICP-MS (Bruker M90) at Syracuse University. The sensitivity of I-127 is tuned to about $80-100 \mathrm{kcps}$ for a $1 \mathrm{ppb}$ standard. The precision of ${ }^{127} \mathrm{I}$ is typically better than $1 \%$ and is not reported individually for each sample. The long-term accuracy is guaranteed by repeated measurements of the reference material JCp-1 [Lu et al., 2010]. The detection limit of I/Ca is usually below $0.1 \mu \mathrm{mol} / \mathrm{mol}$. I/Ca values generated in this process are specific to carbonate, with minor influence from clay, silicate, and organic matter. The liberation of iodine attached to noncarbonate phases during chemical analysis can artificially increase the I/Ca values. This process is particularly important when dealing with sediments relatively high in TOC, because marine organic matter is enriched in iodine.

\subsection{Earth System Modeling}

As an aid to the interpretation of our I/Ca records, we make use of a pair of simulations carried out in a 3-D ocean circulation-based Earth System Model ("cGENIE") [Ridgwell et al., 2007]. For this paper, the climatology and continental arrangements are configured for the Cenomanian-Turonian as described in Monteiro et al. [2012]. Carbon and other biogeochemical cycles in the ocean include $\mathrm{PO}_{4}{ }^{3-}, \mathrm{NO}_{3}{ }^{-}$, and $\mathrm{NH}_{4}{ }^{+}$as nutrients controlling biological export production, plus $\mathrm{O}_{2}, \mathrm{NO}_{3}{ }^{-}$, and $\mathrm{SO}_{4}{ }^{2-}$ as potential oxidants [Ridgwell et al., 2007; Monteiro et al., 2012]. We ran two experiments: one representing potential pre-OAE 2 redox conditions and assuming a modern ocean $\mathrm{PO}_{4}{ }^{3-}$ inventory and $\times 2$ preindustrial $\mathrm{CO}_{2}$ in the atmosphere and another assuming syn-OAE 2 conditions, with $\times 2 \mathrm{PO}_{4}{ }^{3-}$ and $\times 4 \mathrm{CO}_{2}$. These combinations of oceanic $\mathrm{PO}_{4}{ }^{3-}$ and atmospheric $\mathrm{CO}_{2}$ determined by Monteiro et al. [2012] yield the best possible fit to available indicators of ocean floor anoxia and photic zone euxinia. We ran both experiments for 20 kyr to achieve full steady state with respect to patterns of ocean oxygenation and nitrogen cycling. The model code and experimental configurations are identical to those described in Monteiro et al. [2012] and can be replicated via the instructions given in the supporting information.

\section{Results and Discussions}

\subsection{Influence of Diagenesis and Organically Bound lodine}

Bulk carbonate I/Ca signals may be affected by secondary factors in addition to the local upper ocean redox conditions. Mixing with diagenetic carbonate or recrystallization of primary carbonate in anoxic pore waters should lower the I/Ca values, since iodide in anoxic waters cannot be incorporated in carbonate. It is possible that all of the I/Ca values are influenced by diagenesis to some extent. However, the consistency demonstrated by multiproxy and data-model comparisons across different depositional settings suggests that bulk carbonate I/Ca can still serve as a reasonably reliable redox proxy for the suboxic window. Site 1258 on Demerara Rise is the only locality where diagenetic carbonate is common [Erbacher et al., 2004]. The CIE is not very well expressed in the carbonates at the Tarfaya section, indicating possible diagenesis, but the carbonate record in Eastbourne appears largely unaffected by diagenesis and has proved an invaluable geochemical archive [Tsikos et al., 2004]. Minor dolomite is present in the basal part of the Raia del Pedale section but below the CIE interval. As demonstrated below, Tarfaya and the Western Interior Seaway (WIS) sites both have relatively high TOC contents, but the corresponding I/Ca values are much lower than those at sites dominated by low-TOC chalk, suggesting that organic iodine does not always significantly affect I/Ca. Furthermore, the lowest I/Ca values at Tarfaya and in the WIS correlate with high TOC during the OAE. These observations strongly argue against organic matter being an important contaminant of the carbonate I/Ca signal, particularly since our method employs brief exposure to only dilute acid. 


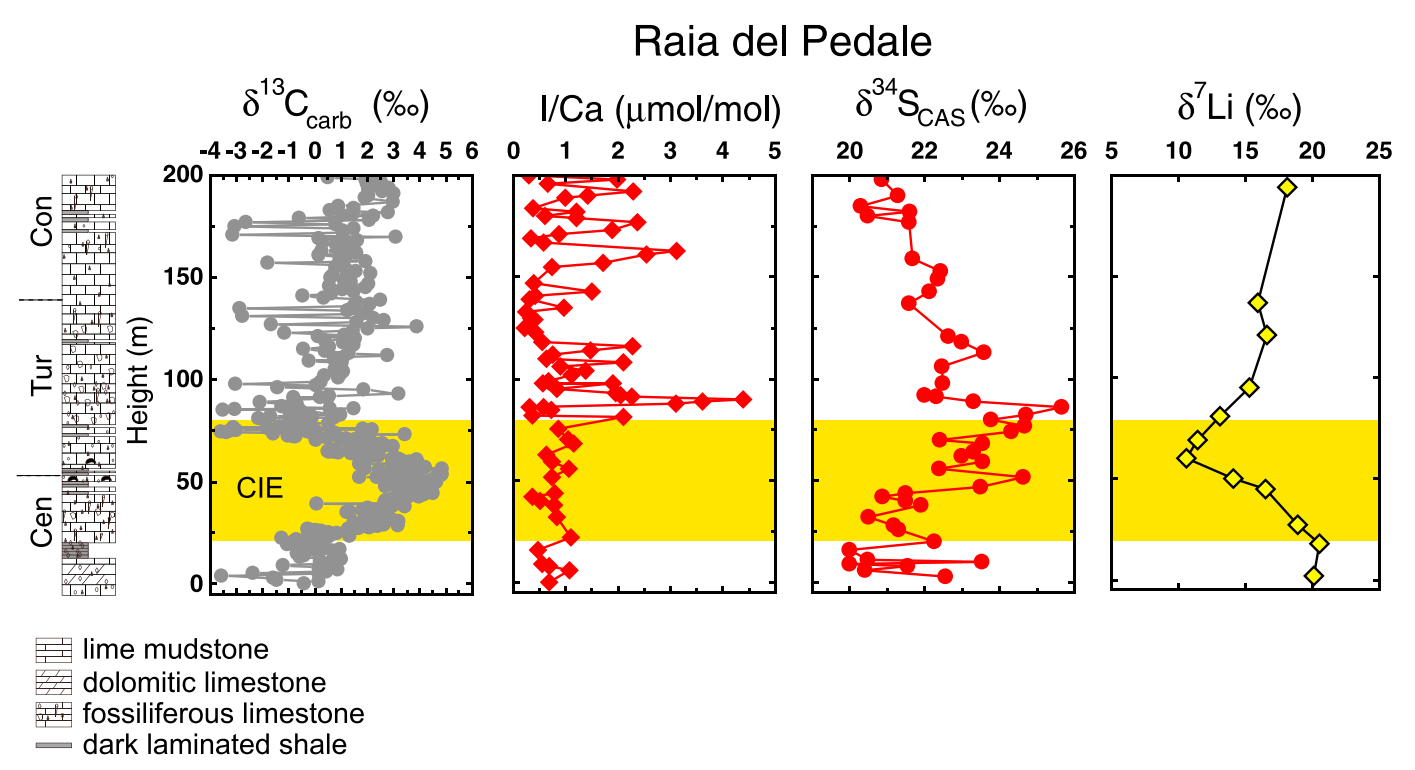

Figure 2. Chemostratigraphic plot for OAE 2 at Raia del Pedale. I/Ca data are from this study, $\delta^{13} \mathrm{C}$ and $\delta^{34} \mathrm{~S}_{\mathrm{CAS}}$ data are from Owens et al. [2013], and $\delta^{7} \mathrm{Li}$ are from Pogge von Strandmann et al. [2013]. The stratigraphic column on the left shows the facies variations [Owens et al., 2013], and the yellow boxes highlight the positive CIE.

\subsection{Shallow-Water Sites}

At all seven sections, the OAE is defined by the positive CIE and ensuing recovery. Raia del Pedale, Italy, is an organic-lean, carbonate-platform section comprising gray lime mudstones containing benthic foraminifera and thick-shelled fossils such as rudists, likely deposited in waters only a few meters deep [Parente et al., 2008] (Figure 1). Although the pre-OAE interval is not exposed in outcrop, the OAE and post-OAE intervals were sampled in detail (Figure 2). During the pre-CIE and $\mathrm{CIE}, \mathrm{I} / \mathrm{Ca}$ values are consistently low at $\sim 1 \mu \mathrm{mol} / \mathrm{mol}$, indicating that the local near-surface waters had relatively low iodate concentrations and were likely proximal to and were mixing with low-oxygen iodide-rich waters brought onto the platform. These conditions were stable locally before and during OAE 2, as indicated by the small variability in I/Ca. Immediately above the level of the CIE, I/Ca briefly increases to above $4 \mu \mathrm{mol} / \mathrm{mol}$ and then returns to low values similar to those of the $\mathrm{OAE}$, but with scattering between $\sim 0.5$ and $2.5 \mu \mathrm{mol} / \mathrm{mol}$. I/Ca values average at $1.2 \mu \mathrm{mol} / \mathrm{mol}$, which are lower than those at pelagic shelf sea sites such as Eastbourne [Lu et al., 2010].

The $\delta^{34} \mathrm{~S}_{\text {CAS }}$ plot for Raia del Pedale shows a gradual increase of up to $6 \%$ during and slightly post-CIE and then declines further up section. The timing of the reversal of $\delta^{34} S_{\text {CAS }}$ trend coincides precisely with the rapid recovery in I/Ca at the end of the CIE (Figure 2), suggesting that a more oxygenated water mass developed post-OAE at this site, conforming to global trends of lower pyrite burial rates. There is no notable relationship between I/Ca ratios and Li isotope profiles [Pogge von Strandmann et al., 2013], suggesting that weathering rates do not control the iodine trend at this locality.

The Aristocrat Angus core in Western Interior Seaway (WIS) records the well-established positive global carbon isotope excursion during the OAE 2 [Sageman et al., 2006; Joo and Sageman, 2014]. Sulfur isotope records have been generated from the Portland core [Adams et al., 2010]; wt \% TOC does not covary systematically with these isotopic records [Sageman et al., 1998; Meyers et al., 2005]. The WIS represents a unique depositional environment among the studied sites. It was a relatively restricted shallow-water seaway (100 to $200 \mathrm{~m}$ water depth [Kauffman and Caldwell, 1993]), where local iodine concentration and speciation should have been very sensitive to organic matter burial and redox conditions. I/Ca ratios from the Aristocrat Angus core [Joo and Sageman, 2014], WIS, are all relatively low ( $<1.2 \mu \mathrm{mol} / \mathrm{mol}$; Figure 3). The I/Ca ratios peak at the early stage of the CIE at levels marked by relatively low TOC content. This observation may indicate a short period characterized by better oxygenated local waters, known as the Plenus Cold Event/Benthic Oxic Event. This event has been linked to climatic cooling and the presence of more oxygenated waters in other regions during the same time interval and was characterized by a 


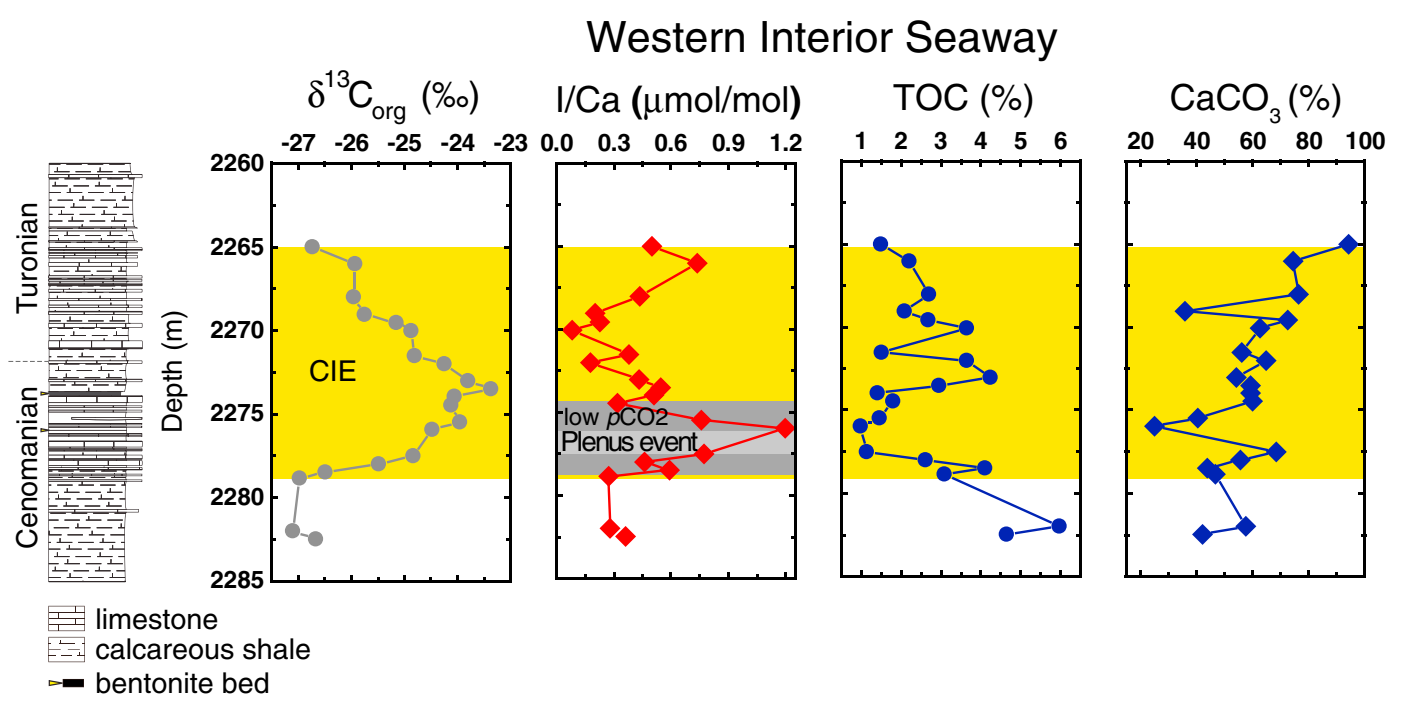

Figure 3. Preliminary $\mathrm{I} / \mathrm{Ca}$ data from the Aristocrat Angus core in the Western Interior Seaway, plotted with wt \% TOC, wt \% $\mathrm{CaCO}_{3}$, and $\delta{ }^{13} \mathrm{C}_{\text {org }}$ [Joo and Sageman, 2014]. The stratigraphic column is revised from Joo and Sageman [2014]. The yellow boxes mark the CIE.

temporary influx of benthic foraminifera in successions otherwise generally barren of benthic fauna [Gale and Christensen, 1996; Keller and Pardo, 2004; Forster et al., 2007; Jarvis et al., 2011; Alegret and Thomas, 2013; Eldrett et al., 2014]. Lower I/Ca and higher TOC following the Plenus Cold Event suggest a return to local more poorly oxygenated conditions during the latter part of the global OAE.

\subsection{Low-Latitude Pelagic Sites}

The tropical proto-Atlantic, particularly the northern South Atlantic, is thought to have hosted the most reducing water masses during OAE 2, based on the relative abundance of biomarkers for phototrophic sulfide oxidizers [Sinninghe Damsté and Koster, 1998; Kuypers et al., 2002]. Our study centered on two locations: Demerara Rise and Tarfaya, Morocco, which are characterized by high TOC levels and serve as tropical peri-equatorial end-member sites (Figure 1). Both sites are within the modeled upwelling region [Topper et al., 2011] dominated by deepwater euxinia and episodic photic-zone euxinia [Kuypers et al., 2002; van Bentum et al., 2009]. Shallow euxinic conditions or upwelling of euxinic deep water should have limited the iodate concentrations in surface waters significantly and set up a steep gradient of iodate concentration between the sea surface and the base of the photic zone.

The I/Ca ratios at Tarfaya are between 0.14 and $1.6 \mu \mathrm{mol} / \mathrm{mol}$ (Figure 4), which are significantly lower than the range at Eastbourne $(\sim 2-5 \mu \mathrm{mol} / \mathrm{mol})$. The I/Ca profile generally changes in the opposite direction to that of carbon isotopes at the same time. During the peak $\mathrm{CIE}, \mathrm{I} / \mathrm{Ca}$ ratios are relatively low, and $\delta^{15} \mathrm{~N}$ values illustrate a broad positive excursion, which may indicate regional upwelling of anoxic waters that promoted both iodate reduction and denitrification and/or anammox processes [Jenkyns et al., 2007].

Site 1258 on Demerara Rise is currently located at a water depth of over $3 \mathrm{~km}$ below modern sea level, although the exact depth of this submarine feature during the mid-Cretaceous remains unresolved. The majority of I/Ca ratios at Site 1258 are below $0.6 \mu \mathrm{mol} / \mathrm{mol}$, with the lowest average ratio among all the sections (Figure 1). The stratigraphic trend for $\mathrm{I} / \mathrm{Ca}$ is broadly the inverse of the trend for carbonate content (Figure 5), which is likely a result of authigenic carbonate diluting/dominating the bulk rock I/Ca signal. Sediments with lighter colors in the studied interval reflect higher carbonate content, identified as layers of significant diagenetic calcite growth [Erbacher et al., 2004]. The high $\mathrm{CaCO}_{3} \%$ and near-zero I/Ca values at core depths of 421 and $428 \mathrm{~m}$ also coincide with peaks of bulk sediment $\mathrm{Mn}$ concentration, interpreted to reflect formation of authigenic Mn-rich carbonate [Hetzel et al., 2009]. Diagenetic carbonate that precipitated in anoxic pore waters does not incorporate iodine, because iodide is the only iodine species in reducing pore water [Kennedy and Elderfield, 1987a, 1987b], and as discussed above, the calcite 


\section{Tarfaya}

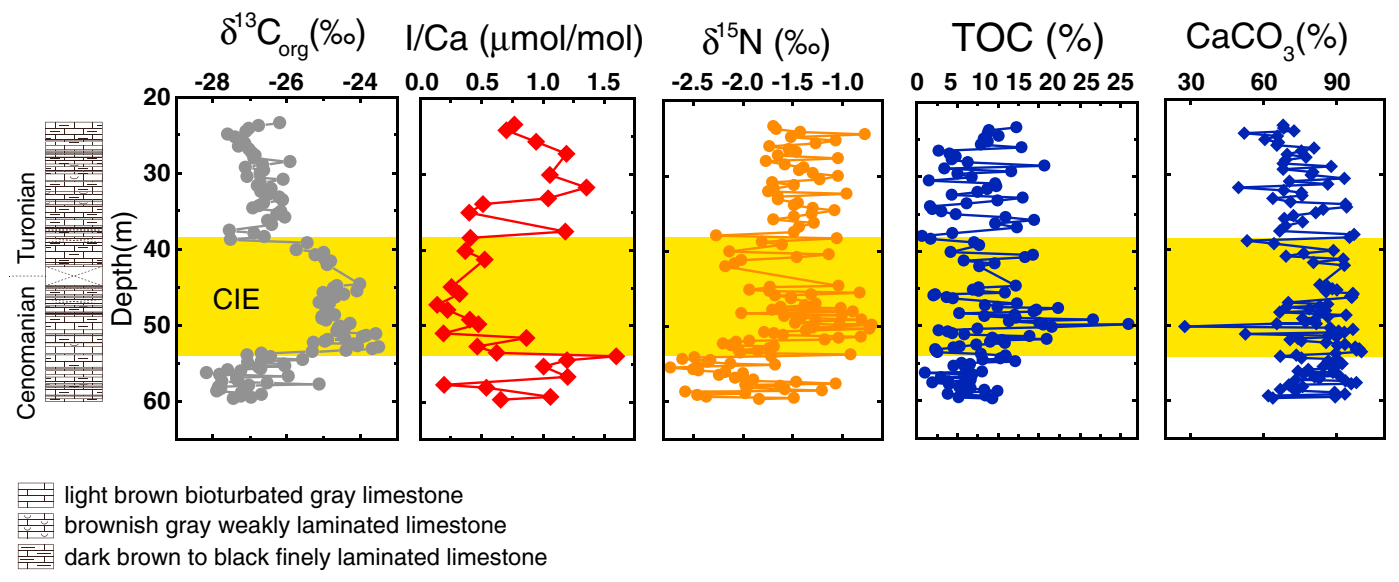

Figure 4. Geochemical and stable isotope data for OAE 2 at Tarfaya (core S57). $\delta^{13} \mathrm{C}_{\text {org }}$ marks the CIE well and covers short periods before and after the CIE. The I/Ca data from bulk carbonate are generated in this study, compared with the $\delta^{15} \mathrm{~N}$, wt \% TOC, and wt $\% \mathrm{CaCO}_{3}$ [Jenkyns et al., 2007]. The highest TOC (\%) correlates with the $\mathrm{CaCO}_{3}(\%)$ minimum and $\delta^{15} \mathrm{~N}$ maximum during the CIE. The stratigraphic column shows variable limestone, revised from Jenkyns et al. [2007]. The CIE is bracketed in yellow boxes.

structure does not accommodate this ion [Lu et al., 2010]. Hence, a significant quantity of diagenetic calcite has likely compromised the primary $\mathrm{l} / \mathrm{Ca}$ record of this particular locality.

However, other proxies suggest that euxinic water masses were present at this site [Hetzel et al., 2009], which may indicate that low $\mathrm{I} / \mathrm{Ca}$ ratios, if not solely due to diagenesis, also represent anoxic conditions near the surface, either by reduction in the local area or by mixing with underlying or laterally adjacent anoxic water masses. Euxinic conditions, below the surface waters, are suggested at Site 1258 by the $\mathrm{Fe}, \mathrm{S}$, and Mo data [Hetzel et al., 2009], and $\delta^{15} \mathrm{~N}$ values suggest upwelling of reduced nitrogen species that fueled planktonic productivity [Higgins et al., 2012]. Consistent with these indicators, the interval analyzed in our study consists of finely laminated black shales with locally developed phosphatic limestone nodules [Erbacher et al., 2005].

\subsection{Midlatitude Pelagic Sites}

New I/Ca data have been generated from a northeast European shelf sea pelagic sequence (South Ferriby in the UK) and from a lithologically similar sequence in the Newfoundland Drifts in the northwest Atlantic [Expedition 342 Scientists, 2012]. The South Ferriby section contains mostly organic-lean chalk, except for an

\section{Demerara Rise}

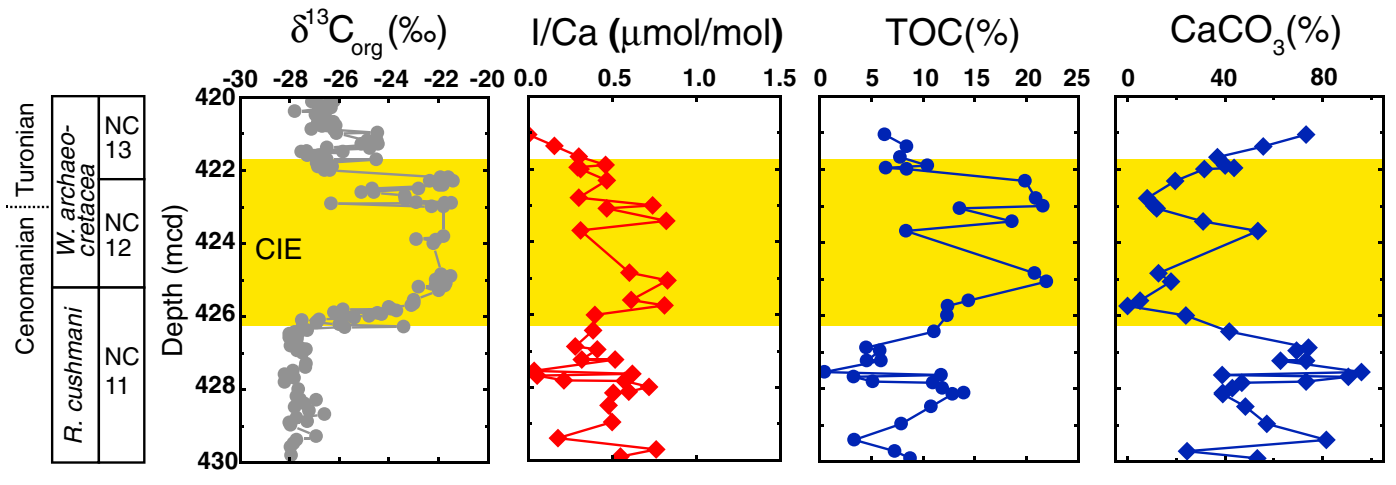

Figure 5. I/Ca for ODP Site 1258 on Demerara Rise, compared with $\delta^{13} \mathrm{C}_{\mathrm{org}}$,wt \% TOC [Erbacher et al., 2005], and wt \% CaCO (iodp.tamu.edu). The biostratigraphic column to the left is from Erbacher et al. [2005]. The scale is meter composite depth. 


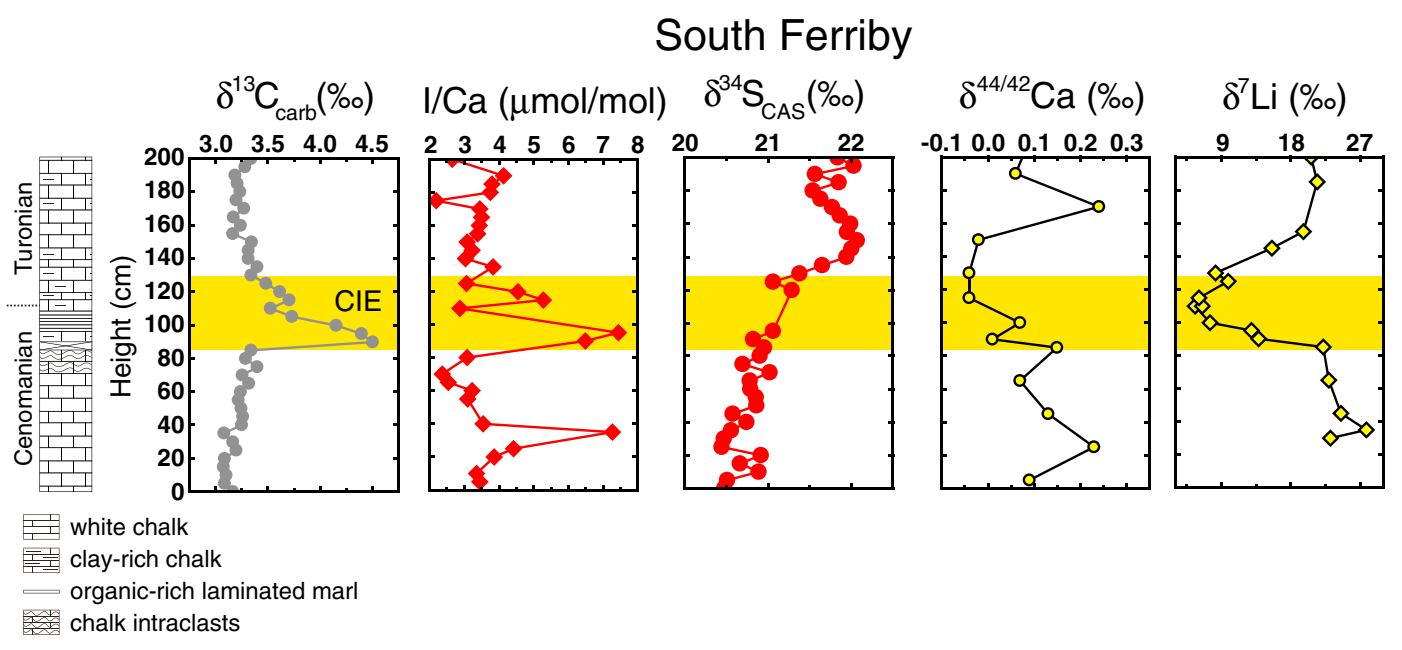

Figure 6. I/Ca data from South Ferriby, compared with $\delta^{13} \mathrm{C}_{\mathrm{carb}}, \delta^{34} \mathrm{C}_{\mathrm{CAS}} \mathrm{Ca}$, and Li isotopes [Blättler et al., 2011; Owens et al., 2013; Pogge von Strandmann et al., 2013]. The stratigraphic column is adapted from Jenkyns et al. [2007]. The yellow boxes bracket the CIE. A hiatus appears at the beginning of the CIE at $\sim 85-90 \mathrm{~cm}$ and is highlighted in the stratigraphic column as a crossed box.

interval of $\sim 10 \mathrm{~cm}$ thick black shale, where TOC rises to $8 \%$ [Jenkyns et al., 2007]. The onset and main part of the CIE are missing at South Ferriby due to a hiatus (Figure 6). The baseline of I/Ca ratios shows a slight decrease starting below the CIE and a gradual increase above the CIE. The preevent baseline varies between 2 and $\sim 4 \mu \mathrm{mol} / \mathrm{mol}$, which is very similar to the range at Eastbourne, indicating an oxygenated water mass. Notably, much higher I/Ca spikes are observed immediately below three clayrich layers in this section (Figure 6). The spikes became increasingly muted during the recovery from the peak CIE. The highest $\mathrm{I} / \mathrm{Ca}$ value $(7.4 \mu \mathrm{mol} / \mathrm{mol})$ found here is the highest among all OAE 2 carbonates. These spikes may be related to local invasion of well-oxygenated water masses with high iodate concentrations.

The $\delta^{34} \mathrm{~S}_{\mathrm{CAS}}$ increases during the $\mathrm{CIE}$ and then starts to decrease at $\sim 140 \mathrm{~cm}$, postdating the $\mathrm{CIE}$, where the $\mathrm{I} / \mathrm{Ca}$ spikes disappear and the baseline rises. Both $\mathrm{Ca}$ and Li isotopes indicate enhanced global weathering [Blättler et al., 2011; Pogge von Strandmann et al., 2013], which may have increased river input of iodine into the ocean and generated higher I/Ca values. These negative $\mathrm{Ca}$ and $\mathrm{Li}$ isotope trends, however, broadly correspond to the interval of low $\mathrm{I} / \mathrm{Ca}$ values in most sections, with the exception of a few spikes at South Ferriby. These oscillations in I/Ca are more likely the result of local episodic oceanographic changes rather than changes in the global iodine budget. Unlike the WIS and Eastbourne sites, the Plenus Cold Event is not recorded from the South Ferriby site. The South Ferriby section is, however, condensed by a factor of $\sim 20$ compared to Eastbourne [Gale et al., 1993], and a hiatus is present near the level of onset of the CIE in this section, making it likely that the Plenus Cold Event was lost from the sedimentary sequence [e.g., Hart and Leary, 1989].

The lithostratigraphy at Site U1407, Newfoundland Drifts, comprises a thick sequence of nannofossil chalk, varying from white to dark gray in color, above and below the black shale $(\sim 0.4 \mathrm{~m}$ near the depth of $232 \mathrm{~m})$. A hiatus appears within the CIE interval at $\sim 231-232 \mathrm{~m}$. Unpublished carbon isotope data (C. Junium) indicate that the CIE bracketing the black shale outlines the OAE 2 interval between 229 and $233 \mathrm{~m}$ (Figure 7). $\mathrm{I} / \mathrm{Ca}$ ratios mostly fluctuate at $2-4 \mu \mathrm{mol} / \mathrm{mol}$ before the $\mathrm{CIE}$, with lower values occasionally observed coinciding with dark chalk. The I/Ca ratios decrease right at the onset level of the $\mathrm{CIE}$, coincident with the base of the black shale. The recovery of $\mathrm{I} / \mathrm{Ca}$ starts with values below $1 \mu \mathrm{mol} / \mathrm{mol}$ and rises slowly to pre-OAE background levels near $3 \mu \mathrm{mol} / \mathrm{mol}$. These data suggest that at this site, the proximal water masses that mix with the local surface waters were generally oxygenated before the OAE, whereas oxygen was rapidly removed from the local surface waters, where the iodine signal is captured, at the onset of the event itself, before slowly returning to background levels.

Eastbourne is among the most studied OAE 2 sites and was included in the first I/Ca investigation of the ancient ocean [Lu et al., 2010]. However, several important observations have since emerged from 


\section{Newfoundland Drifts}

\section{$\mathrm{I} / \mathrm{Ca}(\mu \mathrm{mol} / \mathrm{mol})$}
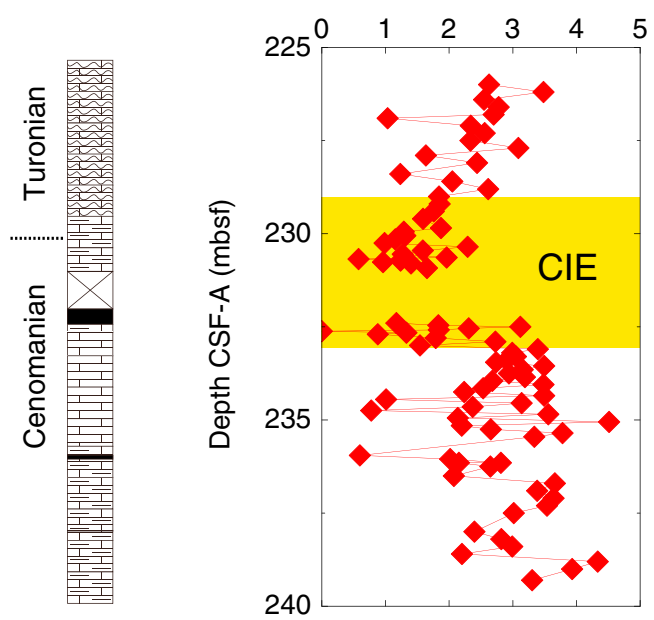

pink foraminiferal nannofossil chalk greenish white nannofossil chalk with foraminifers white nannofossil chalk with foraminifers zeolitic claystone with organic matter

Figure 7. I/Ca record of Site U1407, IODP X342 on Newfoundland Drifts. The $\sim 231-232$ is represented by a crossed box. The $\mathrm{mbsf}=$ meters below seafloor. stratigraphic log is adapted from Expedition 342 Scientists [2012]. A hiatus at

multiproxy comparisons that have refined our view of those data [Blättler et al., 2011; Owens et al., 2013; Pogge von Strandmann et al., 2013]. Relatively high I/Ca values and an excursion to lower $\delta^{34} \mathrm{~S}_{\text {CAS }}$ values are reported from Eastbourne at levels corresponding with the lower part of the CIE (Figure 8) [ $\mathrm{Lu}$ et al., 2010; Owens et al., 2013]. These geochemical data likely record reoxygenation related to the Plenus Cold Event, which occurred during the early phase of OAE 2 and was initially proposed for the European Chalk Sea and the Western Interior Seaway based on southward invasion of boreal faunas [Gale and Christensen, 1996; Keller and Pardo, 2004; Forster et al., 2007]. However, $p \mathrm{CO}_{2}$ records based on stomata and $\Delta^{13} \mathrm{C}$ indicate that the cooling and $\mathrm{CO}_{2}$ drawdown were likely global during the first third of the CIE [Friedrich et al., 2006; Barclay et al., 2010; Jarvis et al., 2011]. The high I/Ca values found at Eastbourne at a level close to the suggested base of the Plenus interval indicate that the spatial extent of oxygenated waters may have been more widespread than previously assumed during this event, although upper ocean geochemical conditions may not have evolved synchronously with bottom water conditions.

\section{Eastbourne}

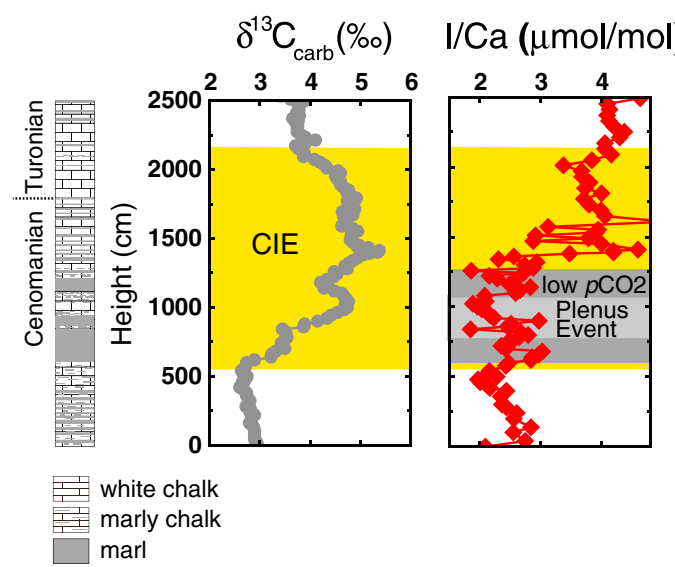

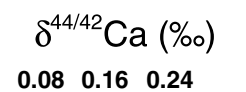
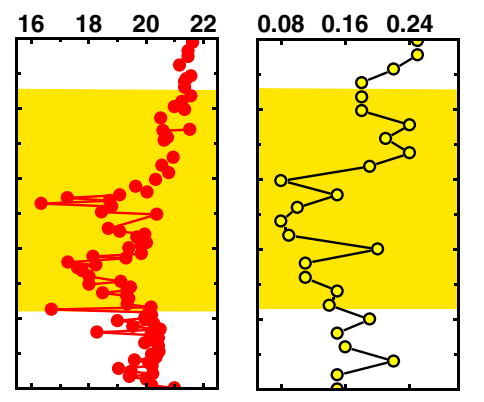

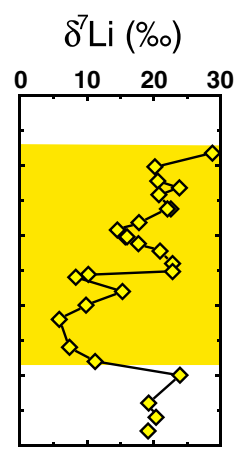

Figure 8. Geochemical and isotope data for Eastbourne. The $\delta^{13} \mathrm{C}_{\text {carb }}$ marks the CIE well, and $\mathrm{I} / \mathrm{Ca}$ and $\delta^{34} \mathrm{~S}_{\mathrm{CAS}}$ indicate redox changes during the studied interval. Plenus Cold Event, also known as the Benthic Oxic Event, is bracketed in light gray box [Tsikos et al., 2004; Owens et al., 2013]. The ranges of low $p \mathrm{CO}_{2}$ and Plenus Cold Event are adapted from Jarvis et al. [2011]. The $\delta^{44 / 42} \mathrm{Ca}$ and $\delta^{7} \mathrm{Li}$ are regarded as proxies of continental weathering rates [Blättler et al., 2011; Pogge von Strandmann et al., 2013]. 


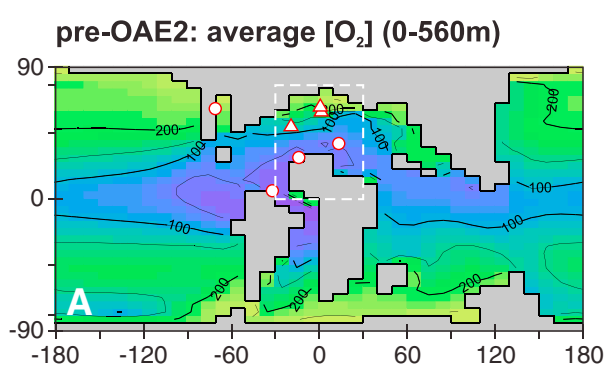

syn-OAE2: average $\left[\mathrm{O}_{2}\right](0-560 \mathrm{~m})$
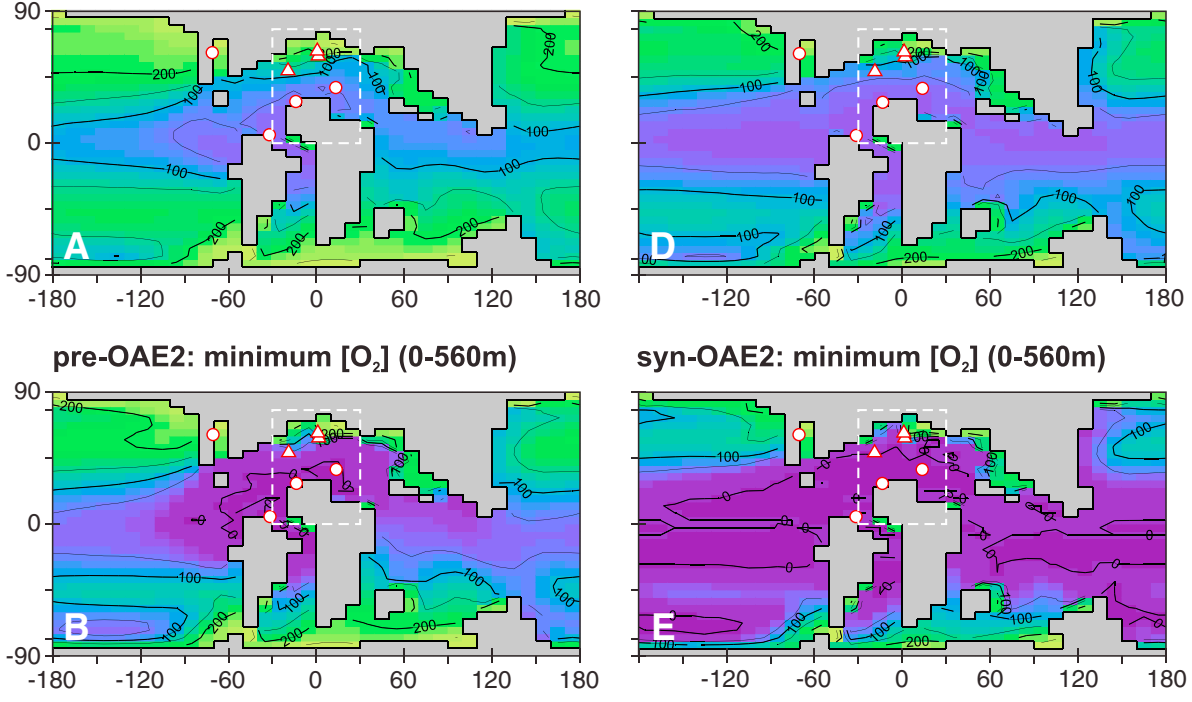

syn-OAE2: minimum $\left[\mathrm{O}_{2}\right](0-560 \mathrm{~m})$

pre-OAE2: regional mean profile

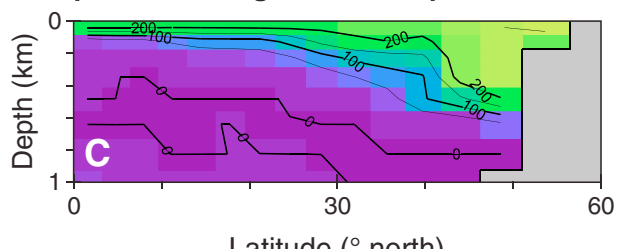

Latitude ( ${ }^{\circ}$ north)

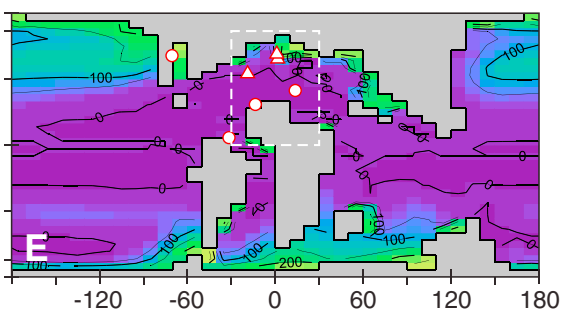

syn-OAE2: regional mean profile

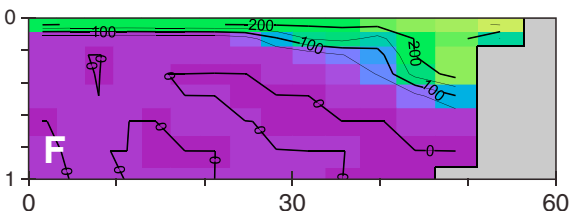

Latitude ( ${ }^{\circ}$ north)

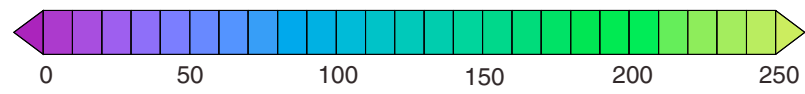

$\left[\mathrm{O}_{2}\right]\left(\mu \mathrm{mol} \mathrm{kg}^{-1}\right)$

Figure 9. Modeled upper water column-dissolved oxygen distributions $(a-c)$ before and $(d-f)$ during OAE2. Figures $9 a$ and $9 d$ show the averaged $\mathrm{O}_{2}$ concentration over the upper $560 \mathrm{~m}$ of water column; Figures $9 \mathrm{~b}$ and 9 e present the minimum $\left[\mathrm{O}_{2}\right]$ in the depth range of $0-560 \mathrm{~m}$. Figures $9 \mathrm{c}$ and $9 \mathrm{f}$ show the cross-sectional views of dissolved oxygen in the proto-Atlantic upper ocean. The extent of longitudinal averaging in these zonal sections is marked by a white dashed rectangle in the map view panels.

\subsection{Data Model Comparisons}

To help visualize patterns emerging from the data, the average and ranges of I/Ca are marked on the map in Figure 1 as a simple generalized representation of the overall conditions throughout the studied interval at each site. Three sites located in the NW proto-Atlantic and European shelf sea (Newfoundland Drifts and Eastbourne and South Ferriby, UK) were generally more oxygenated, as indicated by higher background I/Ca, compared with other regions. The area of this oxygen anomaly is small compared to the majority of the proto-Atlantic localities showing lower I/Ca values. By contrast, the paleo-Pacific ocean has been suggested to be largely oxic [Takashima et al., 2011; Hasegawa et al., 2013], with black shales developed in equatorial regions [Schlanger et al., 1987; Arthur et al., 1988].

Higher dissolved oxygen concentrations are also found in the northeastern proto-Atlantic and European shelf sea prior to OAE 2 in the Earth System Model simulations [Monteiro et al., 2012] (Figure 9). This modeled oxygen maximum occurs only as deep as $\sim 500 \mathrm{~m}$, with the maximum depth decreasing south and away from the continental margin (Figure 9c). Upper water column oxygenation generally decreasing toward the equator is also consistent with proxy data. The I/Ca values are similar for South Ferriby and Eastbourne but are higher than those for Newfoundland Drifts (Figure 1). During OAE 2, oxygen depletion is enhanced throughout much of the ocean in GENIE (Figures 9d-9f). However, the northernmost regions of the proto-Atlantic and European pelagic shelf sea retain an oxygenated water column, consistent with data from South Ferriby showing only very minimal variations in baseline I/Ca during the CIE (Figure 6). 


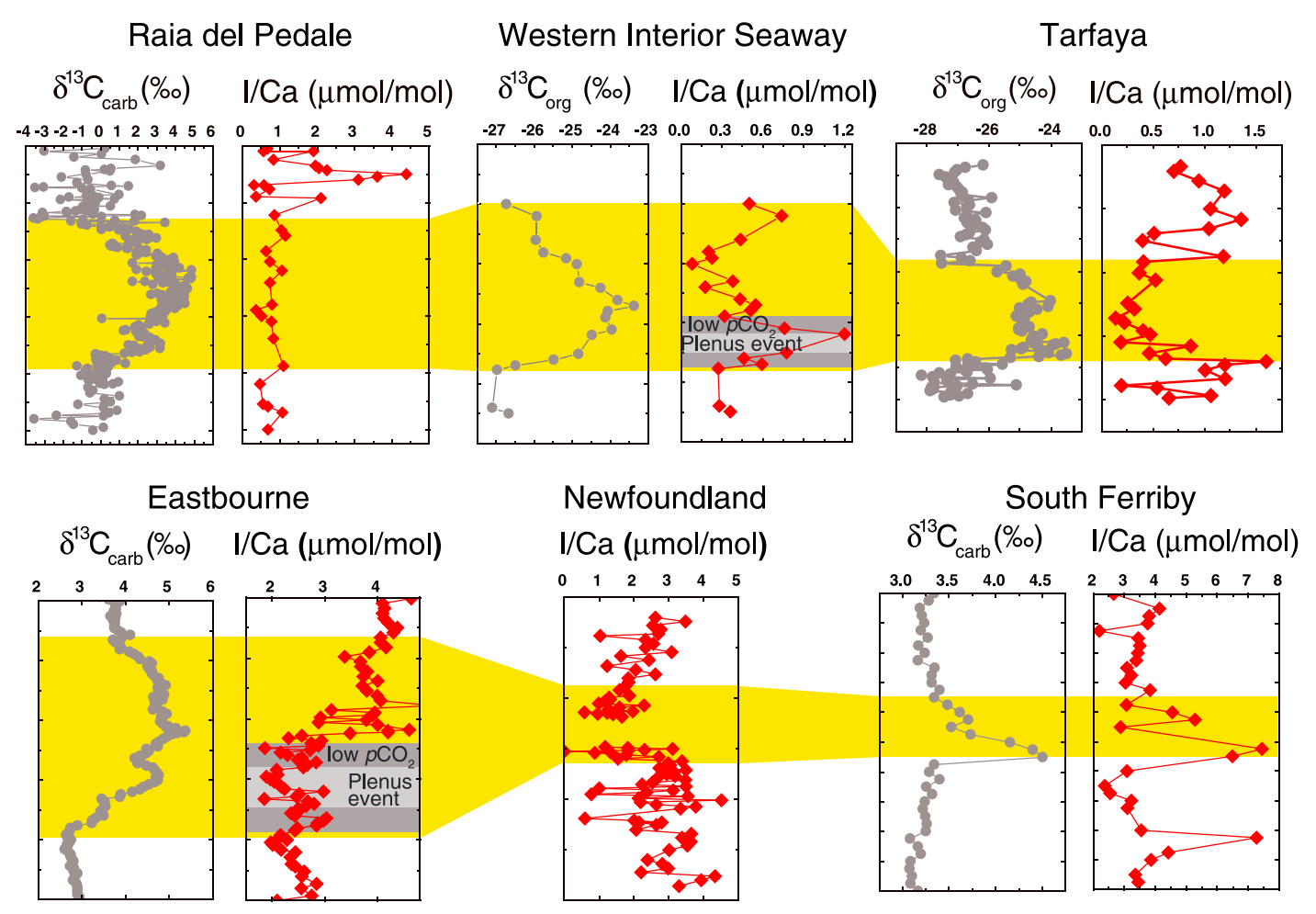

Figure 10. $\mathrm{I} / \mathrm{Ca}$ records correlated by $\delta^{13} \mathrm{C}$ showing distinct local surface water redox evolution. The yellow boxes mark the $\mathrm{CIE}$, except that the onset is missing at South Ferriby due to a hiatus. 

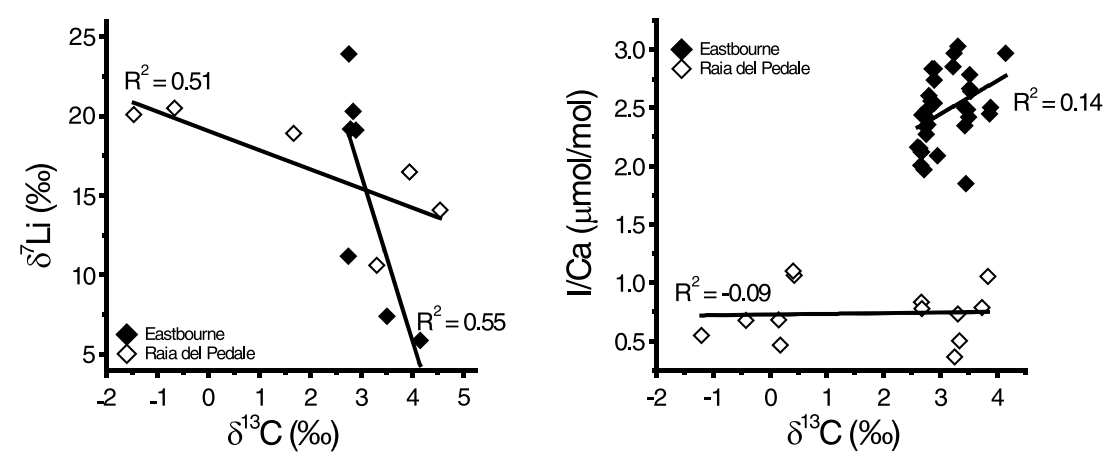

Figure 11. I/Ca and $\delta^{7}$ Li plotted against $\delta^{13} \mathrm{C}$ during the rising limb of the $\mathrm{CIE}$ for Eastbourne and Raia del Pedale.

core. At two pelagic shelf sea sites (Eastbourne and South Ferriby), l/Ca ratios start to decrease below the onset level of the CIE but not necessarily at the same time, indicating that deoxygenation, likely linked to productivity, began to intensify before the global carbon cycle reached its tipping point and initiated the CIE.

At the Eastbourne site, I/Ca shifted to higher values rapidly and simultaneously with $\delta^{13} \mathrm{C}$ during the middle of the CIE (Figure 10) and remained high during the later stage of the CIE. However, I/Ca reached maximum value at the onset of CIE at the Tarfaya site, decreased rapidly, and shows minimum values stratigraphically just above the depth in core with the highest $\delta^{13} \mathrm{C}$ values. The most reducing local/regional conditions in at least part of the Western Interior Seaway are also registered postdating the peak CIE. I/Ca values during the CIE at Raia del Pedale were consistently low with very little variation and do not vary with changes in carbon isotope values. Similarly, I/Ca continued to rise after the CIE at the Newfoundland Drifts site, Eastbourne, and South Ferriby. This compilation of I/Ca data (Figure 10) indicates that the local oxygen levels in the upper ocean were highly heterogeneous across different sites and different ocean basins during $O A E 2$, indicating that redox changes did not necessarily follow the global $\delta^{13} \mathrm{C}$ trend.

\subsection{Marine lodine Budget}

Globally, the marine iodine budget may be affected by increased continental weathering and organic carbon (iodine) burial. If I/Ca records were predominantly artifacts related only to global changes in total iodine concentration (iodide + iodate), the I/Ca trends at different sites would show considerable similarities, as is observed for the isotopic records of $\mathrm{Ca}$, $\mathrm{Li}$, and $\mathrm{C}$ (Figures 2, 6, 8, and 10). Therefore, the differing I/Ca records among the studied sites probably have been affected by local redox conditions more than the potential large-scale changes in total iodine concentration. $\mathrm{Sr}$ isotopes $\left({ }^{87} \mathrm{Sr} /{ }^{86} \mathrm{Sr}\right)$ increased transiently at the onset of OAE 2, such as at Ocean Drilling Program (ODP) Site 551 in the northeast Atlantic [Bralower et al., 1997] and the southern Apennines of Italy [Frijia and Parente, 2008], suggesting a pulse of enhanced continental weathering, although the overall trend is nonradiogenic. Because $\mathrm{Sr}$ isotopes are significantly affected by hydrothermal activity and volcanism, which could overprint the effects of changing weathering rates, this isotopic ratio is not discussed in this study as a weathering proxy [Jenkyns, 2010]. The observed I/Ca trends among sites are very different compared to calcium, lithium, and carbon isotope records. Eastbourne and Raia del Pedale have both $\mathrm{Li}$ isotope and I/Ca data covering the rising interval of $\delta^{13} \mathrm{C}$, a period of rapid global organic carbon burial. The two global proxies $\left(\delta^{7} \mathrm{Li}\right.$ and $\left.\delta^{13} \mathrm{C}\right)$ show slightly better correlation $\left(R^{2}>0.50\right)$, compared to I/Ca versus $\delta^{13} \mathrm{C}\left(R^{2}<0.15\right.$; Figure 11).

Plotting Ca isotopes against $\delta^{13} \mathrm{C}$ and I/Ca separately does not show any major correlation, likely due to the sample resolution and analytical uncertainty in Ca isotope records [Blättler et al., 2011]. Therefore, any global surplus/deficit in the marine iodine budget related to weathering or organic carbon burial was masked by the signal related to dynamic local/regional redox changes in the upper ocean. Although some changes in the iodine budget during global redox shifts and organic carbon burial events are highly likely, this current data set seems to demonstrate that bulk carbonate $\mathrm{I} / \mathrm{Ca}$ is primarily a proxy reflecting local and proximal upper ocean environmental conditions, at least during OAE 2. 


\section{Conclusions}

Multiple I/Ca records suggest that global upper ocean redox conditions during the Cenomanian-Turonian Oceanic Anoxic Event were remarkably variable. The timing of deoxygenation in the upper ocean was not uniform across ocean basins, and the initial development of poorly oxygenated near-surface waters at some Atlantic locations predated the global carbon isotope excursion. A shallow oxygen oasis in the NW proto-Atlantic and European pelagic shelf sea is supported by both higher I/Ca values in multiple sites and by Earth System Modeling. Comparison between weathering indices and I/Ca records suggests that continental input was not a major driver of changes in the marine iodine budget on the time scale of the OAE. The highly variable stratigraphic I/Ca trends at the investigated sites indicate that I/Ca is primarily a proxy for local redox conditions rather than for global iodine cycling during OAEs. I/Ca and $\delta^{34} \mathrm{~S}_{\text {CAS }}$ data both indicate important water mass redox changes, but the latter reflects processes operating on a global scale. This study further demonstrates the potential of $\mathrm{I} / \mathrm{Ca}$ as a unique paleoceanographic proxy for the identification of relative subtle oxygenation changes in Earth's history [Loope et al., 2013; Hardisty et al., 2014; Zhou et al., 2014].

\section{References}

Acknowledgments

Z.L. thanks NSF OCE 1232620. J.D.O. is supported by an Agouron Postdoctoral Fellowship. T.W.L. acknowledges support from the NSF-EAR and NASA-NAI. A.R. thanks the support of NERC via NE/J01043X/1. We are deeply grateful for the constructive and thorough reviews by lan Jarvis and Maya Gomes. I/Ca data can be found in the supporting information.
Adams, D. D., M. T. Hurtgen, and B. B. Sageman (2010), Volcanic triggering of a biogeochemical cascade during oceanic anoxic event 2 , Nat. Geosci., 3, 201-204.

Alegret, L., and E. Thomas (2013), Benthic foraminifera across the Cretaceous/Paleogene boundary in the Southern Ocean (ODP Site 690): Diversity, food and carbonate saturation, Mar. Micropaleontol., 105, 40-51.

Arthur, M. A., E. D. Walter, and M. P. Lisa (1988), Geochemical and climatic effects of increased marine organic carbon burial at the Cenomanian/Turonian boundary, Nature, 335, 714-717.

Arthur, M. A., H. C. Jenkyns, H.-J. Brumsack, and S. O. Schlanger (1990), Stratigraphy, geochemistry, and paleoceanography of organic carbon-rich Cretaceous sequences, in Cretaceous Resources, Events and Rhythms, NATO ASI Ser. C, vol. 304, edited by R. N. Ginsburg and B. Beaudoin, pp. 75-119, Kluwer Acad., Dordrecht, Netherlands.

Barclay, R. S., J. C. McElwain, and B. B. Sageman (2010), Carbon sequestration activated by a volcanic $\mathrm{CO}_{2}$ pulse during ocean anoxic event 2 , Nat. Geosci., 3, 205-208.

Blättler, C. L., H. C. Jenkyns, L. M. Reynard, and G. M. Henderson (2011), Significant increases in global weathering during oceanic anoxic events $1 \mathrm{a}$ and 2 indicated by calcium isotopes, Earth Planet. Sci. Lett., 309, 77-88.

Bluhm, K., P. L. Croot, O. Huhn, G. Rohardt, and K. Lochte (2011), Distribution of iodide and iodate in the Atlantic sector of the southern ocean during austral summer, Deep Sea Res., Part II, 58, 2733-2748.

Bralower, T. J., P. D. Fullagar, C. K. Paull, G. S. Dwyer, and R. M. Leckie (1997), Mid-Cretaceous strontium-isotope stratgraphy of deep-sea sections, Geol. Soc. Am. Bull., 109, 1421-1442.

Broecker, W. S., and E. Clark (2009), Ratio of coccolith $\mathrm{CaCO}_{3}$ to foraminifera $\mathrm{CaCO}_{3}$ in late Holocene deep sea sediments, Paleoceanography, 24, PA3205, doi:10.1029/2009PA001731.

Broecker, W. S., and T.-H. Peng (1982), Tracers in the Sea, Lamont-Doherty Geological Observatory, Columbia Univ., Palisades, N. Y.

Brumsack, H. (2006), The trace metal content of recent organic carbon-rich sediments: Implications for Cretaceous black shale formation, Palaeogeogr. Palaeoclimatol. Palaeoecol., 232, 344-361.

Campos, M., A. M. Farrenkopf, T. D. Jickells, and G. W. Luther (1996), A comparison of dissolved iodine cycling at the Bermuda Atlantic Time-Series station and Hawaii Ocean Time-Series Station, Deep Sea Res., Part II, 43, 455-466.

Campos, M., R. Sanders, and T. Jickells (1999), The dissolved iodate and iodide distribution in the South Atlantic from the Weddell Sea to Brazil, Mar. Chem., 65, 167-175.

Chance, R., et al. (2010), Seasonal and interannual variation of dissolved iodine speciation at a coastal Antarctic site, Mar. Chem., 118, 171-181.

Chance, R., A. R. Baker, L. Carpenter, and T. D. Jickells (2014), The distribution of iodide at the sea surface, Environ. Sci. Process. Impacts, $16,1841$.

Du Vivier, A., D. Selby, B. B. Sageman, I. Jarvis, D. R. Gröcke, and S. Voigt (2014), Marine ${ }^{187} \mathrm{Os} /{ }^{188}$ Os isotope stratigraphy reveals the interaction of volcanism and ocean circulation during oceanic anoxic event 2, Earth Planet. Sci. Lett., 389, 23-33.

Edwards, N. R., and R. Marsh (2005), Uncertainties due to transport-parameter sensitivity in an efficient 3-D ocean-climate model, Clim. Dyn., 24, 415-433, doi:10.1007/s00382-004-0508-8.

Eldrett, J. S., D. Minisini, and S. C. Bergman (2014), Decoupling of the carbon cycle during ocean anoxic event 2, Geology, 42, 567-570.

Elrick, M., R. Molina-Garza, R. Duncan, and L. Snow (2009), C-isotope stratigraphy and paleoenvironment changes across OAE 2 (mid-Cretaceous) from shallow-water platform carbonates of southern Mexico, Earth Planet. Sci. Lett., 277, 295-306.

Erba, E. (2004), Calcareous nannofossils and Mesozoic oceanic anoxic events, Mar. Micropaleontol., 52, 85-106.

Erbacher, J., D. C. Mosher, M. J. Malone, and O. L. S. Party (2004), Drilling probes past carbon cycle perturbations on the Demerara Rise, Eos Trans. AGU, 85, 57-68, doi:10.1029/2004EO060001.

Erbacher, J., O. Friedrich, P. A. Wilson, H. Birch, and J. Mutterlose (2005), Stable organic carbon isotope stratigraphy across oceanic anoxic event 2 of Demerara Rise, western tropical Atlantic, Geochem. Geophys. Geosyst., 6, Q06010, doi:10.1029/2004GC000850.

Expedition 342 Scientists (2012), Paleogene Newfoundland sediment drifts, IODP Preliminary Reports, 342.

Farrenkopf, A. M., and G. W. Luther (2002), lodine chemistry reflects productivity and denitrification in the Arabian Sea: Evidence for flux of dissolved species from sediments of western India into the OMZ, Deep Sea Res., Part II, 49, 2303-2318.

Farrenkopf, A. M., G. W. Luther, V. W. Truesdale, and C. H. Van der Weijden (1997), Sub-surface iodide maxima: Evidence for biologically catalyzed redox cycling in Arabian Sea OMZ during the SW intermonsoon, Deep Sea Res., Part II, 44, 1391-1409.

Forster, A., S. Schouten, K. Moriya, P. A. Wilson, and J. S. Sinninghe Damsté (2007), Tropical warming and intermittent cooling during the Cenomanian/Turonian oceanic anoxic event 2: Sea surface temperature records from the equatorial Atlantic, Paleoceanography, 22, PA1219, doi:10.1029/2006PA001349. 
Forster, A., M. M. M. Kuypers, S. C. Turgeon, H.-J. Brumsack, M. R. Petrizzo, and J. S. Sinninghe Damsté (2008), The Cenomanian/Turonian oceanic anoxic event in the South Atlantic: New insights from a geochemical study of DSDP Site 530A, Palaeogeogr. Palaeoclimatol. Palaeoecol., 267, 256-283.

Friedrich, O., J. Erbacher, and J. Mutterlose (2006), Paleoenvironmental changes across the Cenomanian/Turonian boundary event (oceanic anoxic event 2) as indicated by benthic foraminifera from the Demerara Rise (ODP Leg 207), Rev. Micropaléontol., 49, $121-139$.

Frijia, G., and M. Parente (2008), Strontium isotope stratigraphy in the upper Cenomanian shallow-water carbonates of the southern Apennines: Short-term perturbations of marine ${ }^{87} \mathrm{Sr} /{ }^{86} \mathrm{Sr}$ during the oceanic anoxic event 2, Palaeogeogr. Palaeoclimatol. Palaeoecol., 261, $15-29$.

Gale, A. S., and W. K. Christensen (1996), Occurrence of the belemnite Actinocamax plenus in the Cenomanian of SE France and its significance, Bull. Geol. Soc. Den., 43, 68-77.

Gale, A. S., H. C. Jenkyns, W. J. Kennedy, and R. M. Corfield (1993), Chemostratigraphy versus biostratigraphy: Data from around the Cenomanian-Turonian boundary, J. Geol. Soc. London, 150, 29-32.

Gill, B. C., T. W. Lyons, and H. C. Jenkyns (2011), A global perturbation to the sulfur cycle during the Toarcian oceanic anoxic event, Earth Planet. Sci. Lett., 312, 484-496.

Hardisty, D. S., Z. Lu, N. J. Planavsky, A. Bekker, P. Philippot, X. Zhou, and T. W. Lyons (2014), An iodine record of Paleoproterozoic surface ocean oxygenation, Geology, 42, 619-622.

Harris, D. C. (2006), Quantitative Chemical Analysis, 6th ed., W. H. Freeman, New York.

Hart, M. B., and P. N. Leary (1989), The stratigraphic and palaeogeographic setting of the late Cenomanian "anoxic" event, J. Geol. Soc., 146, 305-310.

Hasegawa, T., J. S. Crampton, P. Schioler, B. Field, K. Fukushi, and Y. Kakizaki (2013), Carbon isotope stratigraphy and depositional oxia through Cenomanian/Turonian boundary sequences (Upper Cretaceous) in New Zealand, Cretaceous Res., 40, 61-80.

Hetzel, A., M. E. Bottcher, U. G. Wortmann, and H.-J. Brumsack (2009), Paleo-redox conditions during OAE 2 reflected in Demerara Rise sediment geochemistry (ODP Leg 207), Palaeogeogr. Palaeoclimatol. Palaeoecol., 273, 302-328.

Higgins, M., R. S. Robinson, J. M. Husson, S. J. Carter, and A. Pearson (2012), Dominant eukaryotic export production during ocean anoxic events reflects the importance of recycled $\mathrm{NH}_{4}{ }^{+}$, Proc. Natl. Acad. Sci. U.S.A., 109, 2269-2274.

Jarvis, I., J. S. Lignum, D. R. Gröcke, H. C. Jenkyns, and M. A. Pearce (2011), Black shale deposition, atmospheric $\mathrm{CO}_{2}$ drawdown and cooling during the Cenomanian-Turonian oceanic anoxic event (OAE 2), Paleoceanography, 26, PA3201, doi:10.1029/2010PA002081.

Jenkyns, H. C. (2003), Evidence for rapid climate change in the Mesozoic-Palaeogene greenhouse world, Philos. Trans. R. Soc. London, Ser. A, $361,1885-1916$.

Jenkyns, H. C. (2010), Geochemistry of oceanic anoxic events, Geochem. Geophys. Geosyst., 11, Q03004, doi:10.1029/2009GC002788.

Jenkyns, H. C., A. Matthews, H. Tsikos, and Y. Erel (2007), Nitrate reduction, sulfate reduction, and sedimentary iron isotope evolution during the Cenomanian-Turonian oceanic anoxic event, Paleoceanography, 22, PA3208, doi:10.1029/2006PA001355.

Jones, C. E., and H. C. Jenkyns (2001), Seawater strontium isotopes, oceanic anoxic events, and seafloor hydrothermal activity in the Jurassic and Cretaceous, Am. J. Sci., 301, 112-149.

Joo, Y. J., and B. B. Sageman (2014), Cenomanian to Campanian carbon isotope chemostratigraphy from the Western Interior Basin, J. Sediment. Res., 84, 529-542.

Kauffman, E. G., and W. G. E. Caldwell (1993), The Western Interior Basin in space and time, in Evolution of the Western Interior Basin, Geol. Assoc. Can. Spec. Pap., vol. 39, edited by W. E. Caldwell and E. G. Kauffman, pp. 1-30.

Keller, G., and A. Pardo (2004), Age and paleoenvironment of the Cenornanian-Turonian global stratotype section and point at Pueblo, Colorado, Mar. Micropaleontol., 51, 95-128.

Kennedy, H. A., and H. Elderfield (1987a), lodine diagenesis in pelagic deep-sea sediments, Geochim. Cosmochem. Acta, 51, $2489-2504$.

Kennedy, H. A., and H. Elderfield (1987b), lodine diagenesis in nonpelagic deep-sea sediments, Geochim. Cosmochem. Acta, 51, 2505-2514.

Kolonic, S., et al. (2005), Black shale deposition on the northwest African Shelf during the Cenomanian/Turonian oceanic anoxic event: Climate coupling and global organic carbon burial, Paleoceanography, 20, PA1006, doi:10.1029/2003PA000950.

Kuroda, J., N. O. Ogawa, M. Tanimizu, M. F. Coffin, H. Tokuyama, H. Kitazato, and N. Ohkouchi (2007), Contemporaneous massive subaerial volcanism and late Cretaceous oceanic anoxic event 2, Earth Planet. Sci. Lett., 256, 211-223.

Kuypers, M. M. M., R. D. Pancost, I. A. Nijenhuis, and J. S. Sinninghe Damsté (2002), Enhanced productivity led to increased organic carbon burial in the euxinic North Atlantic basin during the late Cenomanian oceanic anoxic event, Paleoceanography, 17(4), 1051, doi:10.1029/ 2000PA000569.

Little, S. H., D. Vance, T. W. Lyons, and J. McManus (2015), Controls on trace metal authigenic enrichment in reducing sediments: Insights from modern oxygen-deficient settings, Am. J. Sci., 315, 77-119.

Loope, G. R., L. R. Kump, and M. A. Arthur (2013), Shallow water redox conditions from the Permian-Triassic boundary microbialite: The rare earth element and iodine geochemistry of carbonates from Turkey and south China, Chem. Geol., 351, 195-208.

Lu, Z., H. C. Jenkyns, and R. E. M. Rickaby (2010), lodine to calcium ratios in marine carbonate as a paleo-redox proxy during oceanic anoxic events, Geology, 38, 1107-1110.

Luther, G. W., and T. Campbell (1991), lodine speciation in the water column of the Black Sea, Deep Sea Res., Part I, 38, S875-S882.

Luther, G. W., J. Wu, and J. B. Cullen (1995), Redox chemistry of iodine in seawater: Frontier molecular-orbital theory considerations, in Aquatic Chemistry: Interfacial and Interspecies Processes, Advances in Chemistry Series, vol. 224, edited by C. P. Huang, C. R. Omelia, and J. J. Morgan, pp. 135-155.

Meyers, S. R., B. B. Sageman, and T. W. Lyons (2005), Organic carbon burial rate and the molybdenum proxy: Theoretical framework and application to Cenomanian-Turonian oceanic anoxic event 2, Paleoceanography, 20, PA2002, doi:10.1029/2004PA001068.

Monteiro, F. M., R. D. Pancost, A. Ridgwell, and Y. Donnadieu (2012), Nutrients as the dominant control on the spread of anoxia and euxinia across the Cenomanian-Turonian oceanic anoxic event (OAE 2): Model-data comparison, Paleoceanography, 27, PA4209, doi:10.1029/ 2012 PA002351.

Montoya-Pino, C., S. Weyer, A. D. Anbar, J. Pross, W. Oschmann, B. van de Schootbrugge, and H. W. Arz (2010), Global enhancement of ocean anoxia during oceanic anoxic event 2: A quantitative approach using $U$ isotopes, Geology, 38, 315-318.

Ogg, J. G., and L. A. Hinnov (2012a), Jurassic, in The Geologic Time Scale 2012, edited by F. M. Gradstein et al., pp. 731-791, Elsevier, Amsterdam.

Ogg, J. G., and L. A. Hinnov (2012b), Cretaceous, in The Geologic Time Scale 2012, edited by F. M. Gradstein et al., pp. 793-853, Elsevier, Amsterdam.

Ohkouchi, N., K. Kawamura, Y. Kajiwara, E. Wada, M. Okada, T. Kanamatsu, and A. Taira (1999), Sulfur isotope records around Livello Bonarelli (northern Apennines, Italy) black shale at the Cenomanian-Turonian boundary, Geology, 27, 535-538. 
Orth, C. J., M. Attrep Jr., L. R. Quintana, W. P. Elder, E. G. Kauffman, R. Diner, and T. Willamil (1993), Elemental abundance anomalies in the late Cenomanian extinction interval: a search for the source(s), Earth Planet. Sci. Lett., 117, 189-204.

Owens, J. D., B. C. Gill, H. C. Jenkyns, S. M. Bates, S. Severmann, M. M. M. Kuypers, R. G. Woodfine, and T. W. Lyons (2013), Sulfur isotopes track the global extent and dynamics of euxinia during Cretaceous oceanic anoxic event 2, Proc. Natl. Acad. Sci. U.S.A., 110, 18,407-18,412.

Pancost, R. D., N. Crawford, S. Magness, A. Turner, H. C. Jenkyns, and J. R. Maxwell (2004), Further evidence for the development of photic-zone euxinic conditions during Mesozoic oceanic anoxic events, J. Geol. Soc., 161, 353-364.

Parente, M., G. Frijia, M. Di Lucia, H. C. Jenkyns, R. G. Woodfine, and F. Baroncini (2008), Stepwise extinction of larger foraminifers at the Cenomanian-Turonian boundary: A shallow-water perspective on nutrient fluctuations during oceanic anoxic event 2 (Bonarelli event), Geology, 36, 715-718.

Paytan, A., M. Kastner, D. Campbell, and M. H. Thiemens (2004), Seawater sulfur isotope fluctuations in the Cretaceous, Science, 304, $1663-1665$.

Pearce, M. A., I. Jarvis, and B. A. Tocher (2009), The Cenomanian-Turonian boundary event, OAE 2 and paleoenvironmental change in epicontinental seas: New insights from the dinocyst and geochemical records, Palaeogeogr. Palaeoclimatol. Palaeoecol., 280, 207-234.

Pogge von Strandmann, P. A. E., H. C. Jenkyns, and R. G. Woodfine (2013), Lithium isotope evidence for enhanced weathering during oceanic anoxic event 2, Nat. Geosci., 6, 668-672.

Ridgwell, A., J. C. Hargreaves, N. R. Edwards, J. D. Annan, T. M. Lenton, R. Marsh, A. Yool, and A. Watson (2007), Marine geochemical data assimilation in an efficient Earth System Model of global biogeochemical cycling, Biogeosciences, 4(1), 87-104.

Rue, E. L., G. J. Smith, G. A. Cutter, and K. W. Bruland (1997), The response of trace element redox couples to suboxic conditions in the water column, Deep Sea Res., Part I, 44, 113-134.

Sageman, B. B., J. Rich, C. E. Savrda, T. Bralower, M. A. Arthur, and W. E. Dean (1998), Multiple Milankovitch cycles in the Bridge Creek Limestone (Cenomanian-Turonian), Western Interior Basin, in Stratigraphy and Paleoenvironments of the Cretaceous Western Interior Seaway, SEPM Concepts in Sedimentology and Paleontology, vol. 6, edited by M. A. Arthur and W. E. Dean, pp. 153-171.

Sageman, B. B., S. R. Meyers, and M. A. Arthur (2006), Orbital time scale and new C-isotope record for Cenomanian-Turonian boundary stratotype, Geology, 34, 125-128.

Schlanger, S. O., and H. C. Jenkyns (1976), Cretaceous oceanic anoxic events: Causes and consequences, Geol. Mijnbouw, 55, 179-194.

Schlanger, S. O., M. A. Arthur, H. C. Jenkyns, and P. A. Scholle (1987), The Cenomanian-Turonian oceanic anoxic event, I. Stratigraphy and distribution of organic carbon-rich beds and the marine $\delta^{13} \mathrm{C}$ excursion, in Marine Petroleum Source Rocks, edited by J. Brooks and A. J. Fleet, Geol. Soc. London, Spec. Publ., 26, 371-399.

Schnetger, B., and Y. Muramatsu (1996), Determination of halogens, with special reference to iodine, in geological and biological samples using pyrohydrolysis for preparation and inductively coupled plasma mass spectrometry and ion chromatography for measurement, Analyst, 121, 1627-1631.

Scopelliti, G., A. Bellanca, R. Neri, F. Baudin, and R. Coccioni (2006), Comparative high-resolution chemostratigraphy of the Bonarelli level from the reference Bottaccione section (Umbria-Marche Apennines) and from an equivalent section in NW Sicily: Consistent and contrasting responses to the OAE 2, Chem. Geol., 228, 266-285.

Scopelliti, G., A. Bellanca, E. Erba, H. C. Jenkyns, R. Neri, P. Tamagnini, V. Luciani, and D. Masetti (2008), Cenomanian-Turonian carbonate and organic-carbon isotope records, biostratigraphy and provenance of a key section in NE Sicily, Italy: Palaeoceanographic and palaeogeographic implications, Palaeogeogr. Palaeoclimatol. Palaeoecol., 265, 59-77.

Sinninghe Damsté, J. S., and J. Koster (1998), A euxinic southern North Atlantic Ocean during the Cenomanian/Turonian oceanic anoxic event, Earth Planet. Sci. Lett., 158, 165-173.

Snow, L. J., R. A. Duncan, and T. J. Bralower (2005), Trace element abundances in the Rock Canyon Anticline, Pueblo, Colorado, marine sedimentary section and their relationship to Caribbean plateau construction and oxygen anoxic event 2, Paleoceanography, 20, PA3005 doi:10.1029/2004PA001093.

Staudt, W. J., and M. A. A. Schoonen (1995), Sulfate incorporation into sedimentary carbonates, in Geochemical Transformations of Sedimentary Sulfur: American Chemical Society Symposium Series, vol. 612, edited by M. A. Vairavamurthy and M. A. A. Schoonen, pp. 332-345.

Takashima, R., H. Nishi, T. Yamanaka, T. Tomosugi, A. G. Fernando, K. Tanabe, K. Moriya, F. Kawabe, and K. Hayashi (2011), Prevailing oxic environments in the Pacific Ocean during the mid-Cretaceous oceanic anoxic event 2, Nat. Commun., 2, doi:10.1038/ncomms1233.

Tian, R. C., J. C. Marty, E. Nicolas, J. Chiavérini, D. Ruiz-Ping, and M. D. Pizay (1996), lodine speciation: A potential indicator to evaluate new production versus regenerated production, Deep Sea Res., Part I, 43, 723-738.

Topper, R. P. M., J. Trabucho Alexandre, E. Tuenter, and P. T. Meijer (2011), A regional ocean circulation model for the mid-Cretaceous North Atlantic Basin: Implications for black shale formation, Clim. Past, 7, 277-297.

Tribovillard, N., T. J. Algeo, F. Baudin, and A. Riboulleau (2012), Analysis of marine environmental conditions based on molybdenum-uranian covariation: Application to Mesozoic paleoceanography, Chem. Geol., 324-325, 46-58.

Tsikos, H., et al. (2004), Carbon-isotope stratigraphy recorded by the Cenomanian-Turonian oceanic anoxic event: Correlation and implications based on three key localities, J. Geol. Soc., 161, 711-719.

Turgeon, S., and H. Brumsack (2006), Anoxic versus dysoxic events reflected in sediment geochemistry during the Cenomanian-Turonian Boundary Event (Cretaceous) in the Umbria-Marche Basin of central Italy, Chem. Geol., 234, 321-339.

Turgeon, S., and R. A. Creaser (2008), Cretaceous oceanic anoxic event 2 triggered by a massive magmatic episode, Nature, 454, $323-326$. van Bentum, E. C., A. Hetzel, H. J. Brumsack, A. Forster, G. J. Reichart, and J. S. Sinninghe Damsté (2009), Reconstruction of water column anoxia in the equatorial Atlantic during the Cenomanian-Turonian oceanic anoxic event using biomarker and trace metal proxies, Palaeogeogr. Palaeoclimatol. Palaeoecol., 280, 489-498.

van Helmond, N. A. G. M., I. Ruvalcaba Baroni, A. Sluijs, J. S. Sinninghe Damsté, and C. P. Slomp (2014), Spatial extent and degree of oxygen depletion in the deep proto-North Atlantic basin during oceanic anoxic event 2, Geochem. Geophys. Geosyst., 15, 4254-4266, doi:10.1002/ 2014 GC005528.

Waite, T. J., V. W. Truesdale, and J. Olafsson (2006), The distribution of dissolved inorganic iodine in the seas around Iceland, Mar. Chem., 101, 54-67.

Walker, J. C. G. (1986), Global geochemical cycles of carbon, sulfur and oxygen, Mar. Geol., 70, 159-174.

Weissert, H. (1989), C-isotope stratigraphy as monitor of paleoenvironmental changes: A case study from the early Cretaceous, Surv. Geophys., $10,1-16$.

Westermann, S., D. Vance, V. Cameron, C. Archer, and S. A. Robinson (2014), Heterogeneous oxygenation states in the Atlantic and Tethys Oceans during oceanic anoxic event 2, Earth Planet. Sci. Lett., 404, 178-189. 
Wignall, P. B. (2001), Large igneous provinces and mass extinctions, Earth Sci. Rev., 53, 1-33.

Wong, G. T. F. (1995), Dissolved iodine across the Gulf Stream Front and in the South Atlantic Bight, Deep Sea Res., Part I, 42, 2005-2023.

Wong, G. T. F., and P. G. Brewer (1977), Marine chemistry of iodine in anoxic basins, Geochim. Cosmochim. Acta, 41, 151-159.

Wong, G. T. F., K. Takayanagi, and J. F. Todd (1985), Dissolved iodine in waters overlying and in the Orca Basin Gulf of Mexico, Mar. Chem., 17, 177-183.

Zheng, X.-Y., H. C. Jenkyns, A. S. Gale, D. J. Ward, and G. M. Henderson (2013), Changing ocean circulation and hydrothermal inputs during ocean anoxic event 2 (Cenomanian-Turonian): Evidence from Nd-isotopes in the European shelf sea, Earth Planet. Sci. Lett., 375, 338-348. Zhou, X., E. Thomas, R. E. M. Rickaby, A. M. E. Winguth, and Z. Lu (2014), I/Ca evidence for upper ocean deoxygenation during the Paleocene-Eocene Thermal Maximum (PETM), Paleoceanography, 29, 964-975, doi:10.1002/2014PA002702. 